Raquel B. Gómez-Coca · Larisa E. Kapinos

Antonín Holý · Rosario A. Vilaplana

Francisco González-Vílchez · Helmut Sigel

\title{
Quantification of isomeric equilibria formed by metal ion complexes of 8-[2-(phosphonomethoxy)ethyl]-8-azaadenine (8,8aPMEA) and 9-[2-(phosphonomethoxy)ethyl]-8-azaadenine $(9,8 \mathrm{aPMEA})$. Derivatives of the antiviral nucleotide analogue 9-[2-(phosphonomethoxy) ethyl]adenine (PMEA)
}

Received: 28 May 2004/ Accepted: 29 July 2004/Published online: 20 October 2004

(C) SBIC 2004

Abstract The acidity constants of the two-fold protonated acyclic 9-[2-(phosphonomethoxy)ethyl]-8-azaadenine, $\mathrm{H}_{2}(9,8 \mathrm{aPMEA})^{ \pm}$, and its 8-isomer, 8-[2-(phosphonomethoxy)ethyl]-8-azaadenine, $\mathrm{H}_{2}(8,8 \mathrm{aPMEA})^{ \pm}$, both abbreviated as $\mathrm{H}_{2}(\mathrm{PA})^{ \pm}$, as well as the stability constants of their $\mathrm{M}(\mathrm{H} ; \mathrm{PA})^{+}$and $\mathrm{M}(\mathrm{PA})$ complexes with the metal ions $\mathrm{M}^{2+}=\mathrm{Mg}^{2+}, \mathrm{Ca}^{2+}, \mathrm{Sr}^{2+}, \mathrm{Ba}^{2+}$, $\mathrm{Mn}^{2+}, \mathrm{Co}^{2+}, \mathrm{Ni}^{2+}, \mathrm{Cu}^{2+}, \mathrm{Zn}^{2+}$ or $\mathrm{Cd}^{2+}$, have been determined by potentiometric $\mathrm{pH}$ titrations in aqueous solution at $I=0.1 \mathrm{M}\left(\mathrm{NaNO}_{3}\right)$ and $25^{\circ} \mathrm{C}$. Application of previously determined straight-line plots of $\log K_{\mathrm{M}\left(\mathrm{R}-\mathrm{PO}_{3}\right)}^{\mathrm{M}}$ versus $\mathrm{p} K_{\mathrm{H}\left(\mathrm{R}-\mathrm{PO}_{3}\right)}^{\mathrm{H}}$ for simple phos$\mathrm{ph}(\mathrm{on})$ ate ligands, $\mathrm{R}-\mathrm{PO}_{3}^{2-}$, where $\mathrm{R}$ represents a residue without an affinity for metal ions, proves that for all $\mathrm{M}(\mathrm{PA})$ complexes a larger stability is observed than is expected for a sole phosphonate coordination of the metal ion. This increased stability is attributed to the formation of five-membered chelates involving the ether oxygen present in the aliphatic residue $\left(-\mathrm{CH}_{2}-\mathrm{O}-\mathrm{CH}_{2}-\mathrm{PO}_{3}^{2-}\right)$ of the ligands. The formation degrees of these chelates were calculated; they vary between about $13 \%$ for $\mathrm{Ca}(8,8 \mathrm{aPMEA})$ and $71 \%$ for

\footnotetext{
R. B. Gómez-Coca · L. E. Kapinos · H. Sigel $(\bowtie)$ Department of Chemistry, Inorganic Chemistry, University of Basel, Spitalstrasse 51, 4056 Basel, Switzerland

E-mail: helmut.sigel@unibas.ch

Fax: + 41-61-2671017
}

A. Holý

Institute of Organic Chemistry and Biochemistry, Academy of Sciences, 16610 Prague, Czech Republic

R. A. Vilaplana · F. González-Vílchez Inorganic Chemistry Department, Faculty of Chemistry, University of Seville, 41071 Seville, Spain
$\mathrm{Cu}(8,8 \mathrm{aPMEA})$. The adenine residue has no influence on complex stability except in the $\mathrm{Cu}(9,8 \mathrm{aPMEA})$ and $\mathrm{Zn}(9,8 \mathrm{aPMEA})$ systems, where an additional stability increase attributable to the adenine residue is observed and equilibria between four different isomers exist. This means (1) an open isomer with a sole phosphonate coordination, $\mathrm{M}(\mathrm{PA})_{\mathrm{op}}$, where $\mathrm{PA}^{2-}=9,8 \mathrm{aPMEA}^{2-}$, (2) an isomer with a five-membered chelate involving the ether oxygen, $\mathrm{M}(\mathrm{PA})_{\mathrm{cl} / \mathrm{O}}$, (3) an isomer which contains five- and seven-membered chelates formed by coordination of the phosphonate group, the ether oxygen and the $\mathrm{N} 3$ site of the adenine residue, $\mathrm{M}(\mathrm{PA})_{\mathrm{cl} / \mathrm{O} / \mathrm{N} 3}$, and finally (4) a macrochelated isomer

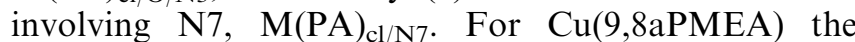
formation degrees are $15,30,48$ and $7 \%$ for $\mathrm{Cu}(\mathrm{PA})_{\mathrm{op}}$, $\mathrm{Cu}(\mathrm{PA})_{\mathrm{cl} / \mathrm{O}}, \mathrm{Cu}(\mathrm{PA})_{\mathrm{cl} / \mathrm{O} / \mathrm{N} 3}$ and $\mathrm{Cu}(\mathrm{PA})_{\mathrm{cl} / \mathrm{N} 7}$, respectively; this proves that the macrochelate involving N7 is a minority species. The situation for the $\mathrm{Cu}(\mathrm{PMEA})$ system, where PMEA ${ }^{2-}$ represents the parent compound, i.e. the dianion of 9-[2-(phosphonomethoxy)ethyl]adenine, is quite similar. The relationship between the antiviral activity of acyclic nucleoside phosphonates and the structures of the various complexes is discussed and an explanation is offered why 9,8aPMEA is biologically active but 8,8 aPMEA is not.

Keywords Antivirals - 8-Azaadenines - Metal ion complexes $\cdot$ Nucleotide analogues $\cdot$ Stability constants

\footnotetext{
Abbreviations (d)ATP ${ }^{4-}$ : (2'-deoxy)adenosine 5'-triphosphate - PMEA: 9-[2-(phosphonomethoxy)ethyl]adenine $\cdot 8,8$ aPMEA: 8 -[2-(phosphonomethoxy)ethyl]-8-azaadenine $\cdot 9,8$ aPMEA: 9-[2-(phosphonomethoxy)ethyl]-8-azaadenine . $I$ : ionic strength $\cdot K_{\mathrm{a}}$ : acidity constant . $\mathrm{M}^{2+}$ : divalent metal ion
} 


\section{Introduction}

The idea to use nucleotide analogues as therapeutic agents has a long tradition $[1,2]$ and all building blocks of a nucleotide have been altered and varied over the years (see, for example, [3] and references therein). Within the large group of acyclic nucleotide analogues $([4,5,6]$ and references therein), two series deserve recognition, i.e. the (S)-3-hydroxy-2-(phosphonomethoxy)propyl (HPMP) derivatives and the (phosphonomethoxy)ethyl (PME) derivatives $[7,8]^{1,2}$. Representative compounds of these series are (S)-9-[3-hydroxy-2-(phosphonomethoxy)propyl]adenine (HPMPA) and 9-[2-(phosphonomethoxy)ethyl]adenine (PMEA) [4, 5, 6, 8], both of which are active against a wide range of viruses, including herpesviruses, poxviruses [9], hepadnaviruses and retroviruses [4, 5, $6,10]$. This discovery [10] goes back to 1986 and in 2002 one of these compounds, namely PMEA, now known as Adefovir $[4,5,6]$, was approved by the US Food and Drug Administration $(\mathrm{FDA})^{3}$ in its oral prodrug form, i.e. its bis(pivaloyloxymethyl)ester (Adefovir dipivoxil $[4,5,6]$ ), for the treatment of hepatitis B patients who suffer from the infection of a DNA virus. For the same treatment, the same compound but under the name Hepsera was also approved in March 2003 for "Community Marketing" by the European Agency for the Evaluation of Medicinal Products $(\text { EMEA })^{4}$.

The dianion of PMEA, which can be considered as an analogue of $\left(2^{\prime}\right.$-deoxy)adenosine $5^{\prime}$-monophosphate $\left[(\mathrm{d}) \mathrm{AMP}^{2-}\right]$ (Fig. $1[11,12,13]$ ) is converted in the cells $[4,5,6]$ into its diphosphorylated form, PMEApp ${ }^{4-}$, which is an analogue of ( $2^{\prime}$-deoxy)adenosine $5^{\prime}$-triphosphate $\left[(\mathrm{d}) \mathrm{ATP}^{4-}\right]$. PMEApp ${ }^{4-}$ is initially recognized by nucleic acid polymerases as a substrate and incorporated in the growing nucleic acid chain, which is then terminated due to the lack of a $3^{\prime}$-hydroxy group. In the polymerase reaction, two metal ions are involved $[14,15$, 16]: one needs to be coordinated to the $\beta, \gamma$-phosphate units and the other to the $\alpha$-phosphate group $[17,18]$ to promote the transfer of a nucleotidyl residue [19]. The observation that PMEApp ${ }^{4-}$ is initially a better substrate than the parent $\mathrm{dATP}^{4-}[20,21]$ was rationalized by the suggestion $[19,22,23]$ that the ether oxygen atom present in PMEA facilitates the $\mathrm{M}^{2+} / \alpha$-phosph(on)ate coordination by the formation of a five-membered

\footnotetext{
${ }^{1}$ For further abbreviations see the legends to Figs. 1 and 2

${ }^{2}$ Species written without a charge either do not carry one or represent the species in general (i.e. independent of their protonation degree); which of the two possibilities applies is always clear from the context. In formulas like $\mathrm{M}(\mathrm{H} ; \mathrm{PA})^{+}$, the $\mathrm{H}^{+}$and $\mathrm{PA}^{2-}$ are separated by a semicolon to facilitate reading, yet they appear within the same parenthesis to indicate that the proton is at the ligand without defining its location

${ }^{3}$ Information regarding US FDA: (2002) Chem Rundschau $(\mathrm{CH}-$ 4501 Solothurn, Switzerland) no. 19 (Oct 8), p 68

${ }^{4}$ Information regarding EMEA as downloaded from the World Wide Web in December 2003: http://www.emea.eu.int/humandocs/ PDFs/EPAR/hepsera/610202en1.pdf
}<smiles>CCCCOP(=O)([O-])OC[C@H]1O[C@@H](n2cnc3c(N)ncnc32)[C@H](O)[C@H]1O</smiles><smiles>CN(C)CCOCCn1cnc2c(N)ncnc21</smiles>

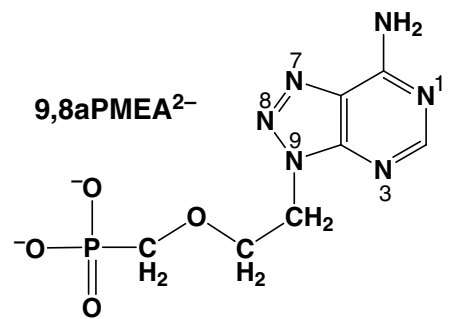

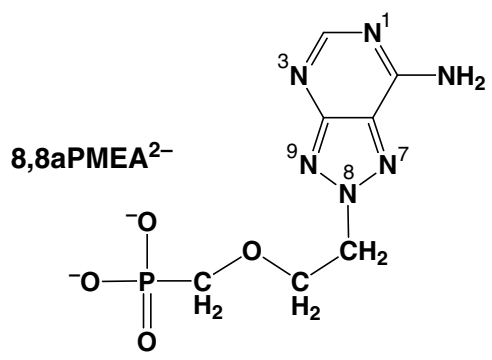

PME-R ${ }^{2-}$<smiles>[R]CCOCP(=O)([O-])[O-]</smiles>

Fig. 1 Chemical structures of adenosine 5 -monophosphate $\left(\mathrm{AMP}^{2-}\right)$ and of the dianions of 9-[2-(phosphonomethoxy)ethyl]adenine (PMEA ${ }^{2-}=$ Adefovir) $[4,5,6]$, 9-[2-(phosphonomethoxy)ethyl]-8-azaadenine $\left(9,8 \mathrm{aPMEA}^{2-}\right)$ and of 8 -[2-(phosphonomethoxy)ethyl]-8-azaadenine $\left(8,8 \mathrm{aPMEA}^{2-}\right)$, together with the structure of PME- $\mathrm{R}^{2-}$, where $\mathrm{R}$ is a non-interacting residue, which represents the metal ion-coordinating properties of the etherphosphonate chain occurring in $\mathrm{PMEA}^{2-}$, 9,8aPMEA ${ }^{2-}$ and $8,8 \mathrm{aPMEA}^{2-}$. A further ligand to be considered in this study is 9-(4-phosphonobutyl)adenine, which is abbreviated as $\mathrm{dPMEA}^{2-}$ $\left(=3^{\prime}\right.$-deoxa-PMEA $\left.{ }^{2-}\right)$ to indicate that its structure corresponds to that of $\mathrm{PMEA}^{2-}$ except that the ether $\mathrm{O}$ atom is replaced by a $\mathrm{CH}_{2}$ group. It should be noted that $\mathrm{AMP}^{2-}$ is shown in its dominating anti conformation $[11,12]$ and that the orientation of $\mathrm{PMEA}^{2-}$ in solution [13] resembles this anti conformation 
chelate ring, as is expressed in a simplified manner in equilibrium 1 :

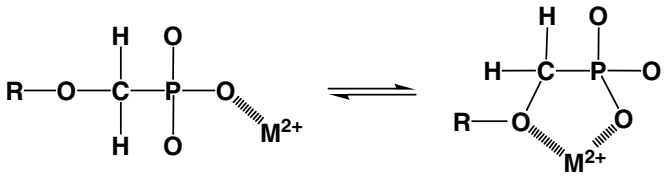

(1)

In fact, it is well known that this ether oxygen is crucial for the biological activity of PMEA and that its replacement by an $\mathrm{S}$ atom [24] or a $\mathrm{CH}_{2}$ unit [20] results in inactive compounds. Similarly, the position of this $\mathrm{O}$ atom within the aliphatic chain is crucial; already the insertion of one additional $\mathrm{CH}_{2}$ unit deprives the resulting analogue of any useful antiviral activity [21, 25]; indeed, the six-membered chelate-ring analogue of equilibrium 1 is considerably less stable with metal ions like $\mathrm{Mg}^{2+}$ and $\mathrm{Zn}^{2+}$ or does even not form at all (Fernández-Botello A, Griesser R, Holý A, Moreno V, Sigel $\mathrm{H}$, to be published).

With the mentioned observations in mind and with the aim to delineate further the structure-function relationship, we studied the metal ion-binding properties of the PMEA analogue 9-[2-(phosphonomethoxy)ethyl]-8-azaadenine (9,8aPMEA) and its isomer 8-[2-(phosphonomethoxy)ethyl]-8-azaadenine (8,8aPMEA) (see Fig. 1). This nucleobase modification, i.e. the replacement of (C8)H by $\mathrm{N}$ [26], was initiated by the more than 50 -yearsold discovery of the antibacterial [27] and antitumor [28] properties of 8-azaguanine, which has led to a continued interest in 8-azapurines and related nucleosides [29, 30, $31,32]$. Interestingly, the present study reveals that the metal ion-binding properties of $9,8 \mathrm{aPMEA}^{2-}$ are very similar to those of $\mathrm{PMEA}^{2-}$ whereas the ones of 8,8aPMEA ${ }^{2-}$ differ, and these differences are also reflected in their biological activity $[26,33]$.

A further point to be emphasized is that the presence of the ether oxygen atom (Fig. 1) in all three nucleotide analogues, i.e. PMEA $^{2-}[22, \quad 23,34,35,36]$, 8,8aPMEA ${ }^{2-}$ and 9,8aPMEA ${ }^{2-}$, gives rise to the already mentioned equilibrium 1 with all the metal ion complexes studied. This property distinguishes the complexes of these analogues from those of their parent nucleotide $\mathrm{AMP}^{2-}$, which does not have this possibility and therefore forms either simply complexes with the phosphate residue or, as in the case of several divalent $3 \mathrm{~d}$ metal ions, in addition macrochelates involving N7 $[37,38,39,40]$; this situation is indicated in a simplified way in the intramolecular equilibrium 2 :

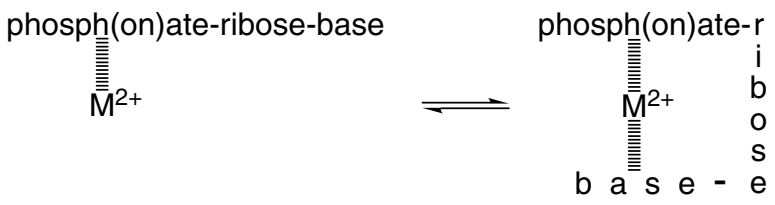

As we shall see below, for the $\mathrm{M}(8,8 \mathrm{aPMEA})$ complexes, equilibrium 1 is of relevance, whereas for some of the
$\mathrm{M}(9,8 \mathrm{aPMEA})$ species the situation is considerably more complicated [41] and both equilibria 1 and 2 are to some extent of relevance.

\section{Materials and methods}

\section{Materials}

Twofold protonated 9-[2-(phosphonomethoxy)ethyl]-8-azaadenine, i.e. $\mathrm{H}_{2}(9,8 \mathrm{aPMEA})^{ \pm}$, and its 8-isomer, 8-[2-(phosphonomethoxy)ethyl]-8-azaadenine, $\mathrm{H}_{2}(8,8 \mathrm{aPMEA})^{ \pm}$, were synthesized by alkylation of 8 azaadenine with a synthon carrying the structural constituents of the required side chain [26]. For the present study, compounds from the same lots used previously [41, 42] were applied. The aqueous solutions of the ligands were freshly prepared daily just before the experiments by dissolving the substance in deionized, ultrapure (MILLIQ185 PLUS; from Millipore, Molsheim, France) $\mathrm{CO}_{2^{-}}$ free water, adjusted to $\mathrm{pH}$ about 8.5 by adding 2 equiv of $0.1 \mathrm{NaOH}$.

The disodium salt of 1,2-diaminoethane- $N, N, N^{\prime}, N^{\prime}$ tetraacetic acid $\left(\mathrm{Na}_{2} \mathrm{H}_{2}\right.$ EDTA), potassium hydrogen phthalate, $\mathrm{HNO}_{3}, \mathrm{NaOH}$ (Titrisol), and the nitrate salts of $\mathrm{Na}^{+}, \mathrm{Mg}^{2+}, \mathrm{Ca}^{2+}, \mathrm{Sr}^{2+}, \mathrm{Ba}^{2+}, \mathrm{Mn}^{2+}, \mathrm{Co}^{2+}, \mathrm{Ni}^{2+}$, $\mathrm{Cu}^{2+}, \mathrm{Zn}^{2+}$ and $\mathrm{Cd}^{2+}$ (all pro analysi) were from Merck (Darmstadt, Germany). All solutions for the potentiometric $\mathrm{pH}$ titrations were prepared with the mentioned ultrapure $\mathrm{CO}_{2}$-free water. The buffer solutions ( $\mathrm{pH} 4.00,7.00,9.00$, based on the NBS scale; now NIST) for calibration were from Metrohm (Herisau, Switzerland).

The exact concentrations of the stock solutions of the divalent metal ions were determined by potentiometric $\mathrm{pH}$ titrations via their EDTA complexes by measuring the equivalents of protons liberated from $\mathrm{H}(\text { EDTA })^{2-}$ upon complex formation with $\mathrm{M}^{2+}$. The exact concentration of the ligand solutions was newly determined for each experiment by evaluation of the corresponding titration pairs, i.e. the differences in $\mathrm{NaOH}$ consumption between solutions with and without ligand (see below).

\section{Potentiometric $\mathrm{pH}$ titrations}

The $\mathrm{pH}$ titration curves for the determination of the equilibrium constants in aqueous solution were recorded with a Metrohm E536 potentiograph connected to a Metrohm E655 dosimat and a Metrohm 6.0222.100 combined macro glass electrode. The $\mathrm{pH}$ calibration of the instrument was carried out with the mentioned buffer solutions of $\mathrm{pH} 4.00,7.00$ and 9.00 . The titer of the $\mathrm{NaOH}$ used was determined with potassium hydrogen phthalate.

The direct $\mathrm{pH}$ meter readings were used in the calculations of the acidity constants, i.e. these constants determined at $I=0.1 \mathrm{M}\left(\mathrm{NaNO}_{3}\right)$ and $25^{\circ} \mathrm{C}$ are so-called practical, mixed or Brønsted constants [43]. 
They may be converted into the corresponding concentration constants by subtracting 0.02 from the listed $\mathrm{p} K_{\mathrm{a}}$ values; this conversion term contains both the junction potential of the glass electrode and the hydrogen ion activity [43, 44]. It should be emphasized that the ionic product of water $\left(K_{\mathrm{w}}\right)$ and the mentioned conversion term do not enter into our calculation procedure because we always evaluate the differences in $\mathrm{NaOH}$ consumption between a pair of solutions, i.e. with and without ligand. The stability constants determined are concentration constants.

All equilibrium constants were calculated by curvefitting procedures in the way and with the equipment described previously $[45,46]$.

Determination of equilibrium constants

The acidity constants $K_{\mathrm{H}_{2}(9,8 \mathrm{aPMEA})}^{\mathrm{H}}$ (Eq. $\left.4 \mathrm{~b}\right)$ and $K_{\mathrm{H}(9,8 \mathrm{aPMEA})}^{\mathrm{H}}$ (Eq. $\left.5 \mathrm{~b}\right)$ of $\mathrm{H}_{2}(9,8 \mathrm{aPMEA})^{ \pm}$, where one proton is at $\mathrm{N} 1$ of the adenine moiety and the other at the phosphonate group, were determined recently [41] and these results were also confirmed now $\left(25^{\circ} \mathrm{C}\right.$; $\left.I=0.1 \mathrm{M}, \quad \mathrm{NaNO}_{3}\right) . \quad$ The stability constants $K_{\mathrm{M}(\mathrm{H} ; 9,8 \mathrm{aPMEA})}^{\mathrm{M}}$ (Eq. $\left.6 \mathrm{~b}\right)$ and $K_{\mathrm{M}(9,8 \mathrm{aPMEA})}^{\mathrm{M}}$ (Eq. $\left.7 \mathrm{~b}\right)$ of the $\mathrm{M}(\mathrm{H} ; 9,8 \mathrm{aPMEA})^{+}$and $\mathrm{M}(9,8 \mathrm{aPMEA})$ complexes, respectively, were determined under the same conditions as the acidity constants [41]. This means that $30 \mathrm{~mL}$ of aqueous $0.83 \mathrm{mM} \mathrm{HNO}_{3}$ were titrated in the presence and absence of $0.4 \mathrm{mM}$ deprotonated ligand under $\mathrm{N}_{2}$ with $1 \mathrm{~mL}$ of $0.03 \mathrm{M} \mathrm{NaOH}$ (the differences in $\mathrm{NaOH}$ consumption between such a pair of titrations were used for the calculations), but $\mathrm{NaNO}_{3}$ was partly or fully replaced by $\mathrm{M}\left(\mathrm{NO}_{3}\right)_{2}\left(25^{\circ} \mathrm{C} ; I=0.1 \mathrm{M}\right)$. The $\mathrm{M}^{2+} / \mathrm{li}-$ gand ratios were 83:1 $\left(\mathrm{Mg}^{2+}, \mathrm{Ca}^{2+}, \mathrm{Sr}^{2+}, \mathrm{Ba}^{2+}\right.$, $\left.\mathrm{Mn}^{2+}\right)$, 75:1 $\left(\mathrm{Mg}^{2+}\right)$, 73.4:1 $\left(\mathrm{Mn}^{2+}\right)$, 55.6:1 $\left(\mathrm{Mg}^{2+}\right.$, $\left.\mathrm{Ca}^{2+}\right), 52: 1\left(\mathrm{Ca}^{2+}\right), 50: 1\left(\mathrm{Mn}^{2+}, \mathrm{Co}^{2+}\right), 49: 1\left(\mathrm{Co}^{2+}\right)$, 41.7:1 $\left(\mathrm{Sr}^{2+}, \mathrm{Ba}^{2+}\right), 28: 1\left(\mathrm{Cd}^{2+}\right), 25: 1\left(\mathrm{Co}^{2+}\right), 14: 1$ $\left(\mathrm{Cd}^{2+}\right), 13: 1\left(\mathrm{Cd}^{2+}\right), 11: 1\left(\mathrm{Cu}^{2+}\right)$ and 5.5:1 $\left(\mathrm{Cu}^{2+}\right)$.

The acidity constants $K_{\mathrm{H}_{2}(8,8 \mathrm{aPMEA})}^{\mathrm{H}}$ (Eq. $4 \mathrm{~b}$ ) and $K_{\mathrm{H}(8,8 \mathrm{aPMEA})}^{\mathrm{H}}$ (Eq. $\left.5 \mathrm{~b}\right)$ of $\mathrm{H}_{2}(8,8 \mathrm{aPMEA})^{ \pm}$were determined by titrating $30 \mathrm{~mL}$ of aqueous $1.27 \mathrm{mM} \mathrm{HNO}_{3}$ in the presence and absence of $0.4 \mathrm{mM}$ deprotonated ligand with $1.3 \mathrm{~mL}$ of $0.03 \mathrm{M} \mathrm{NaOH}\left(25^{\circ} \mathrm{C} ; I=0.1 \mathrm{M}\right.$, $\mathrm{NaNO}_{3}$ ). The differences in $\mathrm{NaOH}$ consumption between such a pair of titrations were used in the calculations. The $\mathrm{pH}$ range from 3.6 to 8.0 was evaluated, which corresponds to an initial formation degree of $48 \%$ for $\mathrm{H}_{2}(8,8 \mathrm{aPMEA})^{ \pm}$and to a final deprotonation degree of $94 \%$ for $8,8 \mathrm{aPMEA}^{2-}$. The results for the two acidity constants are the averages of 13 pairs of independent titrations.

The stability constants $K_{\mathrm{M}(\mathrm{H} ; 8.8 \mathrm{aPMEA})}^{\mathrm{M}}$ (Eq. 6b) and $K_{\mathrm{M}(8,8 \mathrm{aPMEA})}^{\mathrm{M}}$ (Eq. $\left.7 \mathrm{~b}\right)$ of the $\mathrm{M}(\mathrm{H} ; 8,8 \mathrm{aPMEA})^{+}$and M(8,8aPMEA) complexes were determined under the same conditions as the acidity constants, but $\mathrm{NaNO}_{3}$ was partly or fully replaced by $\mathrm{M}\left(\mathrm{NO}_{3}\right)_{2} \quad\left(25^{\circ} \mathrm{C}\right.$;
$I=0.1 \mathrm{M})$. The $\mathrm{M}^{2+}$ /ligand ratios were $83: 1 \mathrm{Mg}^{2+}$, $\left.\mathrm{Ca}^{2+}, \mathrm{Sr}^{2+}, \mathrm{Ba}^{2+}, \mathrm{Mn}^{2+}\right)$, 55.6:1 $\left(\mathrm{Mg}^{2+}, \mathrm{Ca}^{2+}\right), 50: 1$ $\left(\mathrm{Co}^{2+}, \mathrm{Ni}^{2+}\right), 41.7: 1\left(\mathrm{Sr}^{2+}, \mathrm{Ba}^{2+}, \mathrm{Mn}^{2+}\right), 28: 1\left(\mathrm{Zn}^{2+}\right.$, $\left.\mathrm{Cd}^{2+}\right), 25: 1\left(\mathrm{Co}^{2+}, \mathrm{Ni}^{2+}\right), 14: 1\left(\mathrm{Cd}^{2+}\right), 11: 1\left(\mathrm{Cu}^{2+}\right.$, $\left.\mathrm{Zn}^{2+}\right)$ and 5.5:1 $\left(\mathrm{Cu}^{2+}\right)$.

The stability constants were calculated by considering $\mathrm{H}^{+}, \mathrm{H}_{2}(\mathrm{PA})^{ \pm}, \mathrm{H}(\mathrm{PA})^{-}, \mathrm{PA}^{2-}, \mathrm{M}^{2+}, \mathrm{M}(\mathrm{H} ; \mathrm{PA})^{+}$and $\mathrm{M}(\mathrm{PA})$, where $\mathrm{PA}^{2-}=9,8 \mathrm{aPMEA}$ or $8,8 \mathrm{aPMEA}^{2-}$. However, the formation of the monoprotonated $\mathrm{M}(\mathrm{H} ; \mathrm{PA})^{+}$complexes was usually rather small and therefore values for the corresponding constants had to be estimated. These estimations were based on the relationship between complex stability and ligand donor group basicity [47], i.e. $\log K_{\text {stability }}$ versus $\mathrm{p} K_{\mathrm{a}}$ results in a straight line for families of closely related ligands and their complexes. This line is defined by the equation $y=m x+b$, where $x$ represents the $\mathrm{p} K_{\mathrm{a}}$ value, $y$ the logarithm of the calculated stability constant of the corresponding $\mathrm{M}^{2+}$-ligand complex, and $m$ the slope of the straight line, $b$ being the intercept with the $y$-axis. For the slope we used the average of the straight-line equations defined previously for benzimidazole- [48], imidazole- [49] and pyridine-type [50] ligands and their corresponding complexes. The stability constants for $\mathrm{M}(\mathrm{H} ; \mathrm{PA})^{+}$species were provided by two structurally related adenine derivatives, i.e. 9-[2-(phosphonomethoxy)ethyl]adenine (PMEA; $\mathrm{p} K_{\mathrm{H}_{2}(\mathrm{PMEA})}^{\mathrm{H}}=4.16$ [51]) and 9-[2-(phosphonomethoxy)ethyl]-2,6-diaminopurine $\left(\right.$ PMEDAP; $\mathrm{p} K_{\mathrm{H}_{2} \text { (PMEDAP) }}^{\mathrm{H}}=4.82$ [45]); the corresponding stability constant values have been tabulated $[45,51]$. Since the $K_{\mathrm{H}_{2}(\mathrm{PA})}^{\mathrm{H}}$ values are known, $\log$ stability constants for $\mathrm{M}(\mathrm{H} ; \mathrm{PA})^{+}$complexes could be calculated from the PMEA as well as from the PMEDAP data; the average of these two results obtained for each metal ion was then used in the final calculations.

For the 9,8aPMEA systems the experimental data were collected every $0.1 \mathrm{pH}$ unit, beginning at about $1.5 \%$ of complex formation for $\mathrm{M}(\mathrm{H} ; 9,8 \mathrm{aPMEA})^{+}$to a neutralization degree of about $90 \%$ with respect to the species $\mathrm{H}(9,8 \mathrm{aPMEA})^{-}$or until the beginning of the hydrolysis of $\mathrm{M}(\mathrm{aq})^{2+}$, which was evident from the titrations without ligand. The maximal formation degree for the $\mathrm{M}(\mathrm{H} ; 9,8 \mathrm{aPMEA})^{+}$and $\mathrm{M}(9,8 \mathrm{aPMEA})$ species varies between $1.6-8.7 \%$ and $25.8-89.9 \%$, respectively, depending on the metal ion considered. For the corresponding complexes with $\mathrm{Ni}^{2+}, \mathrm{Cu}^{2+}$ and $\mathrm{Zn}^{2+}$, reference [41] should be consulted.

For the 8,8aPMEA systems the experimental data were also collected every $0.1 \mathrm{pH}$ unit from a formation degree of about $0.9 \%$ for the $\mathrm{M}(\mathrm{H} ; 8,8 \mathrm{aPMEA})^{+}$complex to a neutralization degree of about $90 \%$ with regard to the $\mathrm{H}(8,8 \mathrm{aPMEA})^{-}$species or until the beginning of the hydrolysis of $\mathrm{M}(\mathrm{aq})^{2+}$, which was again evident from the titrations in the absence of ligand. The maximal formation degree for the $\mathrm{M}(\mathrm{H} ; 8,8 \mathrm{aPMEA})^{+}$and $\mathrm{M}(8,8 \mathrm{aPMEA})$ complexes varied between $1.5-12.4 \%$ and $22.8-89.5 \%$, respectively. 
It needs to be emphasized that the results showed no dependence on the excess of metal ion concentration employed in the various experiments. The final results for the stability constants of the complexes listed below are the averages of at least five independent titrations for each system.

\section{Results and discussion}

It is well known that nucleobases and their derivatives can undergo self-association via $\pi$ stacking $[11,52,53]$. Therefore, the experimental conditions for the determination of the equilibrium constants by potentiometric $\mathrm{pH}$ titrations $\left(25^{\circ} \mathrm{C} ; I=0.1 \mathrm{M}, \mathrm{NaNO}_{3}\right)$ were selected such that the results summarized below refer to monomeric species. This is ascertained with ligand concentrations of $0.4 \mathrm{mM}$, as has been shown previously for PMEA [51].

\section{Acidity constants of $\mathrm{H}_{3}(8,8 \mathrm{aPMEA})^{+}$ and $\mathrm{H}_{3}(9,8 \mathrm{PPMEA})^{+}$}

The ligands 8,8aPMEA ${ }^{2-}$ and 9,8aPMEA ${ }^{2-}$, abbreviated as $\mathrm{PA}^{2-}$, may accept three protons, two at the phosphonate group and one at the N1 site of the adenine residue [13] (see Fig. 1). Further protonations of the adenine residue are possible at $\mathrm{N} 7$ and $\mathrm{N} 3$, but these protons are released at $\mathrm{p} K_{\mathrm{a}}<0[54,55]$, and therefore they are not considered in this study. At $\mathrm{pH}>0$ the strongest acid that can be derived in aqueous solution from $\mathrm{PA}^{2-}$ is $\mathrm{H}_{3}(\mathrm{PA})^{+}$. Hence, the following three deprotonation reactions need to be considered:

$$
\begin{aligned}
& \mathrm{H}_{3}(\mathrm{PA})^{+} \rightleftharpoons \mathrm{H}_{2}(\mathrm{PA})^{ \pm}+\mathrm{H}^{+} \\
& K_{\mathrm{H}_{3}(\mathrm{PA})}^{\mathrm{H}}=\left[\mathrm{H}_{2}(\mathrm{PA})^{ \pm}\right]\left[\mathrm{H}^{+}\right] /\left[\mathrm{H}_{3}(\mathrm{PA})^{+}\right] \\
& \mathrm{H}_{2}(\mathrm{PA})^{ \pm} \rightleftharpoons \mathrm{H}(\mathrm{PA})^{-}+\mathrm{H}^{+} \\
& K_{\mathrm{H}_{2}(\mathrm{PA})}^{\mathrm{H}}=\left[\mathrm{H}(\mathrm{PA})^{-}\right]\left[\mathrm{H}^{+}\right] /\left[\mathrm{H}_{2}(\mathrm{PA})^{ \pm}\right] \\
& \mathrm{H}(\mathrm{PA})^{-} \rightleftharpoons \mathrm{PA}^{2-}+\mathrm{H}^{+} \\
& K_{\mathrm{H}(\mathrm{PA})}^{\mathrm{H}}=\left[\mathrm{PA}^{2-}\right]\left[\mathrm{H}^{+}\right] /\left[\mathrm{H}(\mathrm{PA})^{-}\right]
\end{aligned}
$$

However, the first proton according to equilibrium $3 \mathrm{a}$ is released from the $\mathrm{P}(\mathrm{O})(\mathrm{OH})_{2}$ group of $\mathrm{H}_{3}(\mathrm{PA})^{+}$, and from the results obtained previously for $\mathrm{H}_{3}\left(\right.$ PMEA) ${ }^{+}$it is known that $\mathrm{p} K_{\mathrm{H}_{3} \text { (PMEA) }}^{\mathrm{H}}=1.22 \pm 0.13$ [13]. The same value may be surmised for the corresponding acidity constant of $\mathrm{H}_{3}(8,8 \mathrm{aPMEA})^{+}$and $\mathrm{H}_{3}(9,8 \mathrm{aPMEA})^{+}$. Hence, for the present study, for which all potentiometric $\mathrm{pH}$ titrations were carried out in the $\mathrm{pH}$ range above 3 (see "Determination of equilibrium constants" and [41, 42]), equilibrium $3 \mathrm{a}$ is actually also not of relevance. Here, only the release of the protons from $\mathrm{H}_{2}(\mathrm{PA})^{ \pm}$need to be considered, i.e. the first one from the $(\mathrm{N} 1) \mathrm{H}^{+}$site (Eq. 4a) and the next one from the $\mathrm{P}(\mathrm{O})_{2}(\mathrm{OH})^{-}$group (Eq. 5a). The corresponding acidity constants are listed in Table 1, together with some related data $[56,57,58,59,60,61,62]$.

The data in Table 1 offer comparisons for many conclusions; a few are given below:

1. Comparison of entries 1 and 2 with entry 3 confirms the conclusion indicated above that the first proton in $\mathrm{H}_{2}(9,8 \mathrm{aPMEA})^{ \pm}$is released from the $(\mathrm{N} 1) \mathrm{H}^{+}$site of the 8 -azaadenine residue [56] and the second one from the monoprotonated phosphonate group.

2. Similarly, the combination of the values from entries 6 and 2 gives those of entry 5 and confirms the corresponding site attributions of the protons in $\mathrm{H}_{2}(\text { PMEA) })^{ \pm}[13,51]$.

3. Comparison of entries 1 and 3 with 5 and 6 demonstrates that replacement of $(\mathrm{C} 8) \mathrm{H}$ by $\mathrm{N}$ acidifies the $(\mathrm{N} 1) \mathrm{H}^{+}$site by about $1.4 \mathrm{p} K$ units; however, this substitution at position 8 of the purine ring has no remarkable effect on the basicity of the phosphonate group.

4. Similarly, the phosphonate group remains largely unaffected if the aliphatic side chain with the ether oxygen atom is moved from position 9 to 8 of the purine ring but the $(\mathrm{N} 1) \mathrm{H}^{+}$site is now acidified only by $\Delta \mathrm{p} K_{\mathrm{a}}=0.6$, as a comparison of entries 4 and 5 demonstrates.

\begin{tabular}{|c|c|c|c|c|}
\hline No & Protonated species ${ }^{\mathrm{c}}$ & $\begin{array}{l}\mathrm{p} K_{\mathrm{H}_{2}(\mathrm{PA})}^{\mathrm{H}} \\
(\mathrm{N} 1) \mathrm{H}^{+}\end{array}$ & $\begin{array}{l}\mathrm{p} K_{\mathrm{H}(\mathrm{PA})}^{\mathrm{H}} \\
\mathrm{P}(\mathrm{O})_{2}(\mathrm{OH})^{-}\end{array}$ & Ref \\
\hline 1 & $\mathrm{H}(9 \mathrm{Me} 8 \mathrm{azaAde})^{+}$ & $2.70^{\mathrm{d}}$ & & [56] \\
\hline 2 & $\mathrm{H}(\mathrm{PME}-\mathrm{R})^{-}$ & & $6.99 \pm 0.04^{\mathrm{e}}$ & ${ }^{-}$ \\
\hline 3 & $\mathrm{H}_{2}(9,8 \mathrm{aPMEA})^{ \pm}$ & $2.73 \pm 0.02$ & $6.85 \pm 0.02$ & $-f, g$ \\
\hline 4 & $\mathrm{H}_{2}(8,8 \mathrm{aPMEA})^{ \pm}$ & $3.56 \pm 0.02$ & $6.79 \pm 0.01$ & $-^{f}$ \\
\hline 5 & $\mathrm{H}_{2}(\mathrm{PMEA})^{ \pm}$ & $4.16 \pm 0.02$ & $6.90 \pm 0.01$ & {$[13,51]$} \\
\hline 6 & $\mathrm{H}(9 \mathrm{MeAde})^{+}$ & $4.10 \pm 0.01$ & & {$[54,55,59]$} \\
\hline 7 & $\mathrm{H}_{2}(\mathrm{dPMEA})^{ \pm}$ & $4.17 \pm 0.02$ & $7.69 \pm 0.01$ & [46] \\
\hline 8 & $\mathrm{CH}_{3} \mathrm{P}(\mathrm{O})_{2}(\mathrm{OH})^{-}$ & & $7.51 \pm 0.01$ & {$[60,61]$} \\
\hline 9 & $\mathrm{H}_{2}(\mathrm{AMP})^{ \pm}$ & $3.84 \pm 0.02$ & $6.21 \pm 0.01$ & {$[37,62]$} \\
\hline
\end{tabular}

Table 1 Negative logarithms of the acidity constants of $\mathrm{H}_{2}(\mathrm{PA})^{ \pm}$, where $\mathrm{PA}^{2-}=8,8 \mathrm{aPMEA}^{2-}$ or $9,8 \mathrm{aPMEA}^{2-}($ Eqs. $4 \mathrm{a}, \mathrm{b}$ and $5 \mathrm{a}, \mathrm{b})$, as determined by potentiometric $\mathrm{pH}$ titrations in aqueous solution at $25^{\circ} \mathrm{C}$ and $I=0.1 \mathrm{M}\left(\mathrm{NaNO}_{3}\right)$, together with the corresponding values of some related systems ${ }^{\mathrm{a}, \mathrm{b}}$

${ }^{\mathrm{a}}$ The error limits given are three times the standard error of the mean value or the sum of the probable systematic errors, whichever is larger

${ }^{\mathrm{b}}$ So-called practical, mixed or Brønsted constants are listed [43]

${ }^{c}$ 9Me8azaAde =9-methyl-8-azaadenine; 9MeAde =9-methyladenine

${ }^{\mathrm{d}}$ Value based on ${ }^{1} \mathrm{H}$ NMR shift experiments $\left(I=0.5 \mathrm{M}, \mathrm{KNO}_{3}\right)$ [56]; a very similar result was obtained in an early spectrophotometric study [57]

${ }^{\mathrm{e}}$ Average of the values due to (phosphonomethoxy)ethane $\left(\mathrm{PME}^{2-}\right.$; $\mathrm{R}=\mathrm{H}$ ) [51] and 1-[2-(phosphonomethoxy)ethyl]cytosine (PMEC ${ }^{2-}$; $\mathrm{R}=$ cytosine residue) $[58]$

${ }^{\mathrm{f}}$ This study

${ }^{\mathrm{g}}$ The values given in [41] are now also confirmed 
5. On the other hand, replacement of the ether oxygen by a methylene group in the alkyl chain has no effect on the basicity of N1 (see entries 5 and 7), but it increases the basicity of the phosphonate group by about $0.8 \mathrm{p} K$ units. This conclusion is further confirmed by comparing entries $2-5$ with 7 and 8 .

6. Of further interest is a comparison of the values for $\mathrm{H}_{2}(\mathrm{AMP})^{ \pm}$(entry 9) with some other data. It is evident that the $(\mathrm{N} 1) \mathrm{H}^{+}$site in $\mathrm{H}_{2}(\mathrm{AMP})^{ \pm}$is only a bit more acidic than the same site in $\mathrm{H}(9 \mathrm{MeAde})^{+}$or $\mathrm{H}_{2}(\mathrm{PMEA})^{ \pm}$(entries 5, 6). This means that the replacement of the ribosyl residue in AMP by the ether oxygen-containing aliphatic chain has little effect on the aromatic ring system. However, the phosphate residue, $-\mathrm{OP}(\mathrm{O})_{2}(\mathrm{OH})^{-}$, of $\mathrm{H}(\mathrm{AMP})^{-}$is by about $0.7 \mathrm{p} K$ units more acidic than the phosphonate group, $-\mathrm{P}(\mathrm{O})_{2}(\mathrm{OH})^{-}$(entries 5, 9). This means that the phosphate group is practically completely deprotonated at physiological $\mathrm{pH}$ (ca. 7.5), whereas the phosphonate group still carries a proton to some extent (about 20\%) [13].

\section{Stability constants of $M(H ; P A)^{+}$and $M(P A)$ complexes for $\mathrm{PA}^{2-}=8,8 \mathrm{aPMEA}{ }^{2-}$ and 9,8aPMEA ${ }^{2-}$}

The experimental data of the potentiometric $\mathrm{pH}$ titrations of all the $\mathrm{M}^{2+} / \mathrm{PA}$ systems can be described completely by equilibria $4 a, 5 a, 6 a$ and $7 a$,

$$
\begin{aligned}
& \mathrm{M}^{2+}+\mathrm{H}(\mathrm{PA})^{-} \rightleftharpoons \mathrm{M}(\mathrm{H} ; \mathrm{PA})^{+} \\
& K_{\mathrm{M}(\mathrm{H} ; \mathrm{PA})}^{\mathrm{M}}=\left[\mathrm{M}(\mathrm{H} ; \mathrm{PA})^{+}\right] /\left(\left[\mathrm{M}^{2+}\right]\left[\mathrm{H}(\mathrm{PA})^{-}\right]\right) \\
& \mathrm{M}^{2+}+\mathrm{PA}^{2-} \rightleftharpoons \mathrm{M}(\mathrm{PA}) \\
& K_{\mathrm{M}(\mathrm{PA})}^{\mathrm{M}}=[\mathrm{M}(\mathrm{PA})] /\left(\left[\mathrm{M}^{2+}\right]\left[\mathrm{PA}^{2-}\right]\right)
\end{aligned}
$$

if the evaluation is not carried into the $\mathrm{pH}$ range where hydroxo complexes form. The acidity constant of equilibrium 8a may be calculated with Eq. 9:

$$
\begin{aligned}
& \mathrm{M}(\mathrm{H} ; \mathrm{PA})^{+} \rightleftharpoons \mathrm{M}(\mathrm{PA})+\mathrm{H}^{+} \\
& K_{\mathrm{M}(\mathrm{H} ; \mathrm{PA})}^{\mathrm{H}}=[\mathrm{M}(\mathrm{PA})]\left[\mathrm{H}^{+}\right] /\left[\mathrm{M}(\mathrm{H} ; \mathrm{PA})^{+}\right] \\
& \mathrm{p} K_{\mathrm{M}(\mathrm{H} ; \mathrm{PA})}^{\mathrm{H}}=\mathrm{p} K_{\mathrm{H}(\mathrm{PA})}^{\mathrm{H}}+\log K_{\mathrm{M}(\mathrm{H} ; \mathrm{PA})}^{\mathrm{M}}-\log K_{\mathrm{M}(\mathrm{PA})}^{\mathrm{M}}
\end{aligned}
$$

The results are listed in Table 2; the stability constants given for the $\mathrm{M}(\mathrm{H} ; \mathrm{PA})^{+}$complexes are only estimates since the formation degree of these species was low (see "Determination of equilibrium constants"). The stability constants of the M(PA) complexes show the usual trends. For the alkaline earth ions the stability decreases with increasing ionic radii, indicating that metal ion binding at the phosphonate group is (at least) in part inner-sphere. For the
Table 2 Logarithms of the stability constants of the $\mathrm{M}(\mathrm{H} ; \mathrm{PA})^{ \pm}$ (Eq. 6a,b) and $\mathrm{M}(\mathrm{PA})$ complexes (Eq. 7a,b), where $\mathrm{PA}^{2-}=$ $8,8 \mathrm{aPMEA}^{2-}$ or $9,8 \mathrm{aPMEA}^{2-}$, as determined by potentiometric $\mathrm{pH}$ titrations, together with the negative logarithms of the acidity constants of the monoprotonated $\mathrm{M}(\mathrm{H} ; \mathrm{PA})^{+}$complexes (Eqs. 8a,b and 9) (aqueous solution; $25^{\circ} \mathrm{C} ; I=0.1 \mathrm{M}, \mathrm{NaNO}_{3}$ ) ${ }^{\mathrm{a}, \mathrm{b}}$

\begin{tabular}{clccc}
\hline $\mathrm{PA}^{2-}$ & $\mathrm{M}^{2+}$ & $\log K_{\mathrm{M}(\mathrm{H} ; \mathrm{PA})}^{\mathrm{M}}$ & $\log K_{\mathrm{M}(\mathrm{PA})}^{\mathrm{M}}$ & $\mathrm{p} K_{\mathrm{M}(\mathrm{H} ; \mathrm{PA})}^{\mathrm{H}}$ \\
\hline 8,8aPMEA & & \\
& $\mathrm{Mg}^{2+}$ & 0.2 & $1.83 \pm 0.07$ & $5.16 \pm 0.26$ \\
& $\mathrm{Ca}^{2+}$ & 0.15 & $1.59 \pm 0.03$ & $5.35 \pm 0.25$ \\
& $\mathrm{Sr}^{2+}$ & 0.1 & $1.37 \pm 0.03$ & $5.52 \pm 0.25$ \\
& $\mathrm{Ba}^{2+}$ & 0.0 & $1.34 \pm 0.04$ & $5.45 \pm 0.25$ \\
& $\mathrm{Mn}^{2+}$ & 0.3 & $2.45 \pm 0.02$ & $4.64 \pm 0.25$ \\
& $\mathrm{Co}^{2+}$ & 0.55 & $2.28 \pm 0.04$ & $5.06 \pm 0.25$ \\
& $\mathrm{Ni}^{2+}$ & 0.9 & $2.27 \pm 0.03$ & $5.42 \pm 0.25$ \\
& $\mathrm{Cu}^{2+}$ & 1.3 & $3.68 \pm 0.06$ & $4.41 \pm 0.26$ \\
& $\mathrm{Zn}^{2+}$ & 1.0 & $2.64 \pm 0.09$ & $5.15 \pm 0.27$ \\
$\mathrm{Cd}^{2+}$ & 1.0 & $2.89 \pm 0.08$ & $4.90 \pm 0.26$ \\
$9,8 \mathrm{aPMEA}$ & $\mathrm{Mg}^{2+}$ & 0.2 & $1.84 \pm 0.04$ & $5.21 \pm 0.25$ \\
& $\mathrm{Ca}^{2+}$ & 0.15 & $1.62 \pm 0.08$ & $5.38 \pm 0.26$ \\
& $\mathrm{Sr}^{2+}$ & 0.1 & $1.41 \pm 0.04$ & $5.54 \pm 0.25$ \\
& $\mathrm{Ba}^{2+}$ & 0.0 & $1.38 \pm 0.05$ & $5.47 \pm 0.26$ \\
& $\mathrm{Mn}^{2+}$ & 0.15 & $2.49 \pm 0.04$ & $4.51 \pm 0.25$ \\
& $\mathrm{Co}^{2+}$ & 0.4 & $2.33 \pm 0.04$ & $4.92 \pm 0.25$ \\
& $\mathrm{Ni}^{2+}$ & 0.7 & $2.25 \pm 0.08$ & $5.30 \pm 0.26$ \\
& $\mathrm{Cu}^{2+}$ & 0.95 & $3.98 \pm 0.04$ & $3.82 \pm 0.25$ \\
& $\mathrm{Zn}^{2+}$ & 0.8 & $2.82 \pm 0.09$ & $4.83 \pm 0.27$ \\
$\mathrm{Cd}^{2+}$ & 0.75 & $2.93 \pm 0.06$ & $4.67 \pm 0.26$
\end{tabular}

${ }^{\mathrm{a}}$ For the error limits, see footnote (a) of Table 1. The error limits $(3 \sigma)$ of the derived data, in the present case for column 5 , were calculated according to the error propagation after Gauss

${ }^{\mathrm{b}}$ The values for the $\mathrm{Ni}^{2+}, \mathrm{Cu}^{2+}$ and $\mathrm{Zn}^{2+}$ systems of 9,8aPMEA are taken from [41]. The titrations with $\mathrm{Zn}^{2+}$ were hampered by precipitation, i.e. the $\mathrm{pH}$ range suitable for the evaluation of the stability constants was restricted [41]

${ }^{\mathrm{c}}$ The stability constants listed for the $\mathrm{M}(\mathrm{H} ; \mathrm{PA})^{+}$complexes as well as the error limits ( $\pm 0.25 \log$ units) are estimates

divalent $3 \mathrm{~d}$ metal ions the long-standing experience $[51,63]$ is confirmed that the stabilities of phosph(on)ate-metal ion complexes often do not strictly follow $[34,38,39,45,62,64,65,66]$ the Irving-Williams sequence [67], an observation in accord with the fact that in ligands of this kind the phosph(on)ate group is always the main binding site $[35,36,38,39,62,65]$ in $\mathrm{M}(\mathrm{PA})$ complexes (see the next section and Fig. 2 below).

As far as the $\mathrm{M}(\mathrm{H} ; \mathrm{PA})^{+}$complexes are concerned, it is evident that the evaluation of potentiometric $\mathrm{pH}$ titration data only allows the determination, or in the present case estimation, of their stability constants. Further information is required to detect the binding sites of the proton and the metal ion. At first, one may ask where the proton is located because binding of a metal ion to a protonated ligand commonly leads to an acidification of the ligand-bound proton [68, 69]. Indeed, the acidity constants of the $\mathrm{M}(\mathrm{H} ; \mathrm{PA})^{+}$complexes given in column 5 of Table 2 are about 1.3$3 \mathrm{p} K$ units smaller than $\mathrm{p} K_{\mathrm{H}(\mathrm{PA})}^{\mathrm{H}}$ (Table 1), but about 0.9-2.8 log units larger than $\mathrm{p}_{\mathrm{H}_{2}(\mathrm{PA})}^{\mathrm{H}}$. This comparison shows that the proton in $\mathrm{M}(\mathrm{H} ; \mathrm{PA})^{+}$is clearly located at the phosphonate group; hence, one may tentatively 


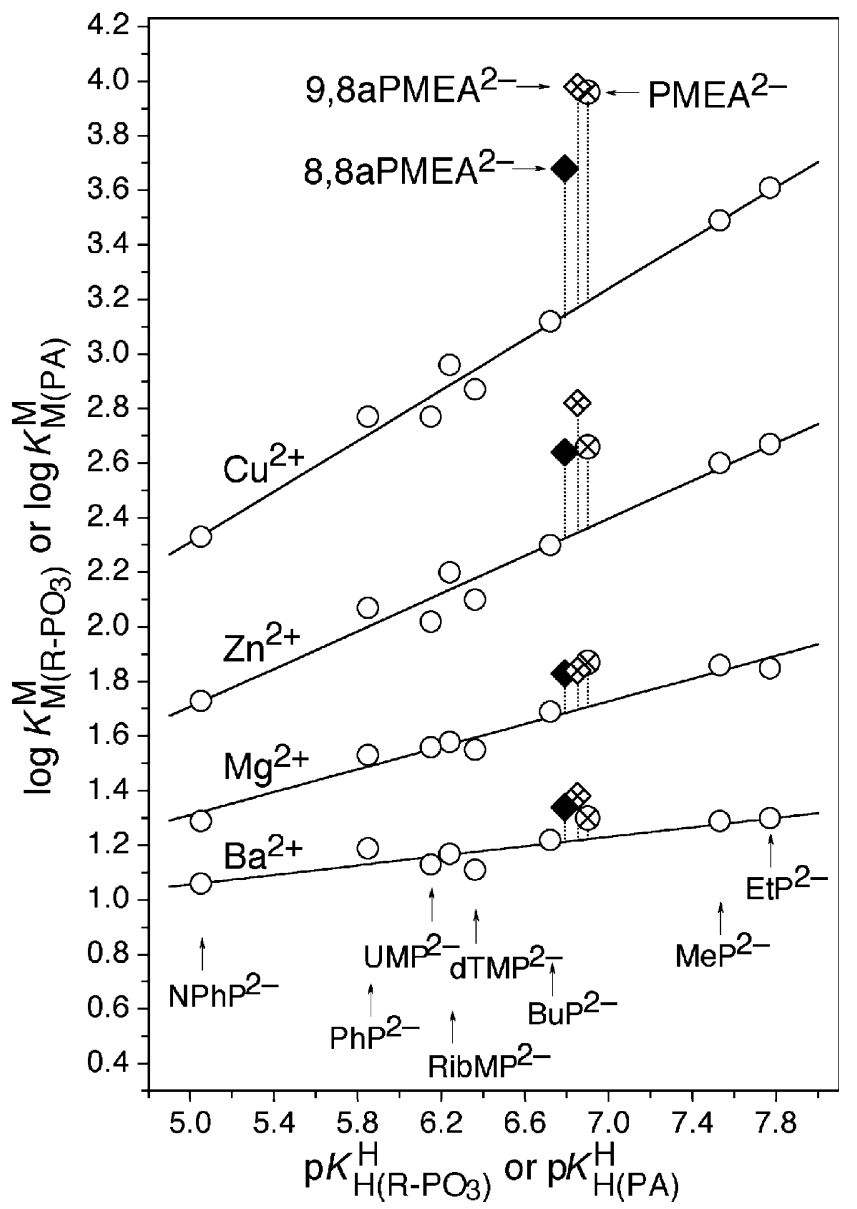

Fig. 2 Evidence for an enhanced stability of several M(9,8aPMEA) (crossed diamonds), $\mathrm{M}(8,8 \mathrm{aPMEA})$ (solid diamonds) and M(PMEA) (crossed circles) complexes, based on the relationship between $\log K_{\mathrm{M}\left(\mathrm{R}-\mathrm{PO}_{3}\right)}^{\mathrm{M}}$ and $\mathrm{p} K_{\mathrm{H}\left(\mathrm{R}-\mathrm{PO}_{3}\right)}^{\mathrm{H}}$ for $\mathrm{M}\left(\mathrm{R}-\mathrm{PO}_{3}\right)$ complexes of some simple phosphate monoester and phosphonate ligands $\left(\mathrm{R}-\mathrm{PO}_{3}^{2-}\right)$ (open circles): 4-nitrophenyl phosphate $\left(\mathrm{NPhP}^{2-}\right)$, phenyl phosphate $\left(\mathrm{PhP}^{2-}\right)$, uridine $5^{\prime}$-monophosphate $\left(\mathrm{UMP}^{2-}\right)$, D-ribose 5 -monophosphate $\left(\mathrm{RibMP}^{2-}\right)$, thymidine $\left[=1-\left(2^{\prime}-\right.\right.$ deoxy- $\beta$-D-ribofuranosyl)thymine] $5^{\prime}$-monophosphate $\left(\mathrm{dTMP}^{2-}\right), n$-butyl phosphate $\left(\mathrm{BuP}^{2-}\right)$, methanephosphonate $\left(\mathrm{MeP}^{2-}\right)$ and ethanephosphonate $\left(\mathrm{EtP}^{2-}\right)$ (from left to right). The least-squares lines (Eq. 10) are drawn through the corresponding eight data sets (open circles) taken from [73] for the phosphate monoesters and from [51] for the phosphonates. The points due to the equilibrium constants for the $\mathrm{M}^{2+} / 9,8$ aPMEA (crossed diamonds) and $\mathrm{M}^{2+} /$ 8,8aPMEA (solid diamonds) systems are based on the values listed in Tables 1 and 2; those for the $\mathrm{M}^{2+} /$ PMEA systems (crossed circles) are from [51]. The vertical broken lines emphasize the stability differences from the reference lines; they equal log $\Delta_{\mathrm{M} / 9,8 \mathrm{aPMEA}}$ and $\log \Delta_{\mathrm{M} / 8,8 \mathrm{aPMEA}}$, as defined in Eqs. 11a and $11 \mathrm{~b}$, for the $\mathrm{M}(9,8 \mathrm{aPMEA})$ and $\mathrm{M}(8,8 \mathrm{aPMEA})$ complexes, respectively. All the plotted equilibrium constants refer to aqueous solutions at $25^{\circ} \mathrm{C}$ and $I=0.1 \mathrm{M}\left(\mathrm{NaNO}_{3}\right)$

assume that the metal ion is bound preferentially to the nucleobase, since a monoprotonated phosphonate group is only a weak binding site. Indeed, this suggestion agrees with evidence obtained previously for other related $\mathrm{M}(\mathrm{H} ; \mathrm{PA})^{+}$species $[35,36,51]$. It is further supported by the observation that the estimated stabilities of the
$\mathrm{M}(\mathrm{H} ; \mathrm{PA})^{+}$complexes follow the Irving-Williams sequence [67], as is typical for metal ion binding to nitrogen donor sites [63], the preferred site most likely being N7 [70, 71].

\section{Evidence for an enhanced stability of the M(8,8aPMEA) and $M(9,8 a P M E A)$ complexes}

The 8,8aPMEA ${ }^{2-}$ and 9,8aPMEA ${ }^{2-}$ ligands offer four potential binding sites for the coordination of metal ions: the two-fold negatively charged phosphonate group, the ether oxygen of the $-\mathrm{CH}_{2} \mathrm{CH}_{2}-\mathrm{O}-\mathrm{CH}_{2}-\mathrm{PO}_{3}^{2-}$ chain (see Fig. 1) and the adenine residue with its $\mathrm{N} 7$ and N3 sites; the N1 is not accessible by a phosphonatebound metal ion $[34,51]$. The phosphonate group is clearly the primary binding site for all metal ions considered in this study and therefore any participation in metal ion binding of one (or more) of the other potential sites has to be reflected in a relative stability increase [47]. Hence, it is necessary to define the stability of a pure $\mathrm{PO}_{3}^{2-} / \mathrm{M}^{2+}$ interaction. This can be done by applying the previously defined [34, 65, 72] straight-line correlations which are based on $\log K_{\mathrm{M}\left(\mathrm{R}-\mathrm{PO}_{3}\right)}^{\mathrm{M}}$ versus $\mathrm{p} K_{\mathrm{H}\left(\mathrm{R}-\mathrm{PO}_{3}\right)}^{\mathrm{H}}$ plots for simple phosphate monoesters [73] and phosphonates [51]; these ligands are abbreviated as $\mathrm{R}-\mathrm{PO}_{3}^{2-}$, where $\mathrm{R}$ represents a non-coordinating residue. The parameters for the corresponding straight-line equations, which are defined by Eq. 10,

$\log K_{\mathrm{M}\left(\mathrm{R}-\mathrm{PO}_{3}\right)}^{\mathrm{M}}=m \times \mathrm{p} K_{\mathrm{H}\left(\mathrm{R}-\mathrm{PO}_{3}\right)}^{\mathrm{H}}+b$

have been tabulated $[34,51,65,72]$, i.e. the slopes $m$ and the intercepts $b$ with the $y$ axis. Hence, with a known $\mathrm{p} K_{\mathrm{a}}$ value for the deprotonation of a $\mathrm{P}(\mathrm{O})_{2}(\mathrm{OH})^{-}$group an expected stability constant can be calculated for any phosph(on)ate-metal ion complex.

Corresponding plots of $\log K_{\mathrm{M}\left(\mathrm{R}-\mathrm{PO}_{3}\right)}^{\mathrm{M}}$. versus $\mathrm{p} K_{\mathrm{H}\left(\mathrm{R}-\mathrm{PO}_{3}\right)}^{\mathrm{H}}$ according to Eq. 10 are ${ }_{\mathrm{shown}}^{\mathrm{M}\left(\mathrm{R}-\mathrm{PO}_{3}\right)}$ in Fig. 2 for $1: 1$ complexes of $\mathrm{Ba}^{2+}, \mathrm{Mg}^{2+}, \mathrm{Zn}^{2+}$ and $\mathrm{Cu}^{2+}$, as examples, with the data points (open circles) of the eight simple ligand systems used [51, 73] for the determination of the straight reference lines [51]. The data points for the $\mathrm{M}^{2+}$ complexes of PMEA ${ }^{2-}$ and its 8-aza analogues are for all four metal ion systems clearly above the reference lines, thus proving an increased stability for all 12 complexes considered though the stability enhancements for the $\mathrm{Mg}^{2+}$ and $\mathrm{Ba}^{2+}$ complexes are relatively small.

Furthermore, it is evident that the stability increase for the $\mathrm{Mg}^{2+}$ and $\mathrm{Ba}^{2+}$ complexes is within the error limits identical for all three ligands and this indicates that here equilibrium 1 is of relevance, since the affinity of the alkali earth metal ions toward $\mathrm{N}$ sites is small [63]. This observation contrasts with that made for the $\mathrm{Cu}^{2+}$ and $\mathrm{Zn}^{2+}$ complexes since their stability enhancement evidently differs for $8,8 \mathrm{aPMEA}^{2-}$ and 
9,8aPMEA ${ }^{2-}$, indicating that here at least to some extent the adenine residue is (also) involved in metal ion binding. This is confirmed by the data points for the $\mathrm{Cu}^{2+}$ complexes of PMEA ${ }^{2-}$ and 9,8aPMEA ${ }^{2-}$, which indicate the same stability enhancement, and for $\mathrm{Cu}$ (PMEA) the involvement in metal ion binding of the adenine residue has been proven. The apparent difference for the corresponding $\mathrm{Zn}^{2+}$ complexes should not be interpreted, since the stability constant for $\mathrm{Zn}$ (PMEA) could not be measured due to precipitation [51]; it is an estimate only [22, 23] and, in fact, the corresponding stability constants are within their (large) error limits identical (see below).

Stability enhancements like those seen in Fig. 2 can be quantified by the differences between the experimentally (exptl) measured stability constants and those calculated (calcd) according to Eq. 10; this difference is defined in Eq. 11a,b:

$$
\begin{aligned}
\log \Delta_{\mathrm{M} / \mathrm{PA}} & =\log K_{\mathrm{M}(\mathrm{PA}) \operatorname{exptl}}^{\mathrm{M}}-\log K_{\mathrm{M}(\mathrm{PA}) \text { calcd }}^{\mathrm{M}} \\
& =\log K_{\mathrm{M}(\mathrm{PA})}^{\mathrm{M}}-\log K_{\mathrm{M}(\mathrm{PA}) \text { op }}^{\mathrm{M}}(=\log \Delta)
\end{aligned}
$$

where the expressions $\log K_{\mathrm{M}(\mathrm{PA}) \text { calcd }}^{\mathrm{M}}$ and $\log K_{\mathrm{M}(\mathrm{PA}) \text { op }}^{\mathrm{M}}$ are synonymous because the calculated value equals the stability constant of the "open" isomer, $\mathrm{M}(\mathrm{PA})_{\mathrm{op}}$

Table 3 Stability constant comparisons for the M(PA) complexes, where $\mathrm{PA}^{2-}=8,8 \mathrm{aPMEA}^{2-}$ or $9,8 \mathrm{aPMEA}^{2-}$, according to Eq. 11a,b; that is, between the experimentally measured (exptl) and the calculated (calcd) log stability constants, the latter being based on the reference-line equations (Eq. 10) $[34,51,72]$ and the $\mathrm{p} K_{\mathrm{H}(\mathrm{PA})}^{\mathrm{H}}$ values (Table 1) of the monoprotonated $\mathrm{H}(\mathrm{PA})^{-}$species (aqueous

\begin{tabular}{|c|c|c|c|c|}
\hline \multirow[t]{2}{*}{$\mathrm{PA}^{2-}$} & \multirow[t]{2}{*}{$\mathrm{M}^{2+}$} & \multicolumn{2}{|l|}{$\log K_{\mathrm{M}(\mathrm{PA})}^{\mathrm{M}}$} & \multirow[t]{2}{*}{$\log \Delta_{\mathrm{M} / \mathrm{PA}}$} \\
\hline & & exptl $^{\mathrm{b}}$ & calcd & \\
\hline 8,8 $\mathrm{aPMEA}^{2}$ & $\begin{array}{l}\mathrm{Mg}^{2+} \\
\mathrm{Ca}^{2+} \\
\mathrm{Sr}^{2+} \\
\mathrm{Ba}^{2+} \\
\mathrm{Mn}^{2+} \\
\mathrm{Co}^{2+} \\
\mathrm{Ni}^{2+} \\
\mathrm{Cu}^{2+} \\
\mathrm{Zn}^{2+} \\
\mathrm{Cd}^{2+}\end{array}$ & $\begin{array}{l}1.83 \pm 0.07 \\
1.59 \pm 0.03 \\
1.37 \pm 0.03 \\
1.34 \pm 0.04 \\
2.45 \pm 0.02 \\
2.28 \pm 0.04 \\
2.27 \pm 0.03 \\
3.68 \pm 0.06 \\
2.64 \pm 0.09 \\
2.89 \pm 0.08\end{array}$ & $\begin{array}{l}1.68 \pm 0.03 \\
1.53 \pm 0.05 \\
1.29 \pm 0.04 \\
1.21 \pm 0.04 \\
2.30 \pm 0.05 \\
2.07 \pm 0.06 \\
2.09 \pm 0.05 \\
3.14 \pm 0.06 \\
2.33 \pm 0.06 \\
2.63 \pm 0.05\end{array}$ & $\begin{array}{l}0.15 \pm 0.08 \\
0.06 \pm 0.06 \\
0.08 \pm 0.05 \\
0.13 \pm 0.06 \\
0.15 \pm 0.05 \\
0.21 \pm 0.07 \\
0.18 \pm 0.06 \\
0.54 \pm 0.08 \\
0.31 \pm 0.11 \\
0.26 \pm 0.09\end{array}$ \\
\hline $9,8 \mathrm{aPMEA}^{2-}$ & $\begin{array}{l}\mathrm{Mg}^{2+} \\
\mathrm{Ca}^{2+} \\
\mathrm{Sr}^{2+} \\
\mathrm{Ba}^{2+} \\
\mathrm{Mn}^{2+} \\
\mathrm{Co}^{2+} \\
\mathrm{Ni}^{2+} \\
\mathrm{Cu}^{2+} \\
\mathrm{Zn}^{2+} \\
\mathrm{Cd}^{2+}\end{array}$ & $\begin{array}{l}1.84 \pm 0.04 \\
1.62 \pm 0.08 \\
1.41 \pm 0.04 \\
1.38 \pm 0.05 \\
2.49 \pm 0.04 \\
2.33 \pm 0.04 \\
2.25 \pm 0.08 \\
3.98 \pm 0.04 \\
2.82 \pm 0.09 \\
2.93 \pm 0.06\end{array}$ & $\begin{array}{l}1.70 \pm 0.03 \\
1.53 \pm 0.05 \\
1.29 \pm 0.04 \\
1.22 \pm 0.04 \\
2.31 \pm 0.05 \\
2.08 \pm 0.06 \\
2.10 \pm 0.05 \\
3.17 \pm 0.06 \\
2.35 \pm 0.06 \\
2.65 \pm 0.05\end{array}$ & $\begin{array}{l}0.14 \pm 0.05 \\
0.09 \pm 0.09 \\
0.12 \pm 0.06 \\
0.16 \pm 0.06 \\
0.18 \pm 0.06 \\
0.25 \pm 0.07 \\
0.15 \pm 0.09 \\
0.81 \pm 0.07 \\
0.47 \pm 0.11 \\
0.28 \pm 0.08\end{array}$ \\
\hline
\end{tabular}
solution; $\left.25^{\circ} \mathrm{C} ; I=0.1 \mathrm{M}, \mathrm{NaNO}_{3}\right)^{\mathrm{a}}$

\footnotetext{
${ }^{\mathrm{a}}$ For the error limits, see footnote (a) of Table 2

${ }^{\mathrm{b}}$ From column 4 of Table 2
}

(see, for example, equilibria 1 and 2), in which only a $\mathrm{PO}_{3}^{2-} / \mathrm{M}^{2+}$ interaction occurs. In columns $3-5$ of Table 3 the values for the three terms of Eq. 11a,b are listed. All $\log \Delta_{\mathrm{M} / \mathrm{PA}}$ values being positive proves that at least one further binding site, next to the phosphonate group, must be involved in all these $\mathrm{M}(\mathrm{PA})$ complexes.

\section{Evidence for an ether oxygen interaction in the M(PA) complexes and quantification of the corresponding intra- molecular equilibrium}

It is obvious that the vertical distance from the marked data points in Fig. 2 for the M(PA) complexes to their reference lines reflects the "intensity" of the participation of any other binding site, next to the phosphonate group, in metal ion binding and that this "intensity" is quantified by Eqs. 11a,b. To learn which of the above-mentioned additional binding sites (see also Fig. 1) is responsible for the observed stability enhancements, we have listed in column 2 of Table 4 the $\log \Delta_{\mathrm{M} / \mathrm{PME}-\mathrm{R}}$ values (according to Eqs. 11a,b) which are solely attributable to the formation of fivemembered chelates as seen in equilibrium 1 because the ligand PME- $\mathrm{R}^{2-}$ does not offer any other binding site except the ether oxygen, aside from the phosphonate group itself (see Fig. 1). The corresponding data $\log \Delta_{\mathrm{M} / 8,8 \mathrm{aPMEA}}$ and $\log \Delta_{\mathrm{M} / 9,8 \mathrm{aPMEA}}$ for the M(8,8aPMEA $)$ and M(9,8aPMEA) complexes $[=\mathrm{M}(\mathrm{PA})]$ are given in columns 3 and 4 of Table 4 , respectively, and a comparison with those in column 2 is best done by calculating the differences according to Eq. 12:

$\Delta \log \Delta_{\mathrm{M} / \mathrm{PA} / \mathrm{PME}-\mathrm{R}}=\log \Delta_{\mathrm{M} / \mathrm{PA}}-\log \Delta_{\mathrm{M} / \mathrm{PME}-\mathrm{R}}$

The corresponding results are listed in columns 6 and 7 for $8,8 \mathrm{aPMEA}^{2-}$ and 9,8aPMEA ${ }^{2-}$, respectively. It is obvious that all the values in column 6 are zero within the error limits, meaning that the stability enhancements $\log \Delta_{\mathrm{M} / 8,8 \mathrm{aPMEA}}$ correspond to those of $\log \Delta_{\mathrm{M} / \mathrm{PME}-\mathrm{R}}$ and that therefore equilibrium 1 operates in all the M(8,8aPMEA) systems and that only a $\mathrm{M}^{2+}$-ether oxygen interaction is responsible for the increased complex stability. Exactly the same is true for the M(9,8aPMEA) systems, with two exceptions: in $\mathrm{Cu}(9,8 \mathrm{aPMEA})$ and $\mathrm{Zn}(9,8 \mathrm{aPMEA})$ a further interaction next to the one with the ether oxygen must occur, as is evident from the results listed in column 7 .

Since it has been shown previously $[41,46]$ that in the $\mathrm{Cu}$ (PMEA) species not only equilibrium 1 with the ether oxygen interaction operates but that also the adenine residue is involved, mainly via N3 and to a small extent also via N7 [46], we have summarized the $\log \Delta_{\mathrm{M} / \mathrm{PMEA}}$ values in column 5 of Table 4 and the differences according to Eq. 12 in column 8 at the 
Table 4 Comparison of the stability enhancements according to Eq. 11a,b as observed for the M(8,8aPMEA) and M(9,8aPMEA) complexes (Table 3, column 5), with the corresponding values determined earlier for the related M(PME-R) [58] and M(PMEA) complexes $[22,23,51]$ (aqueous solution; $\left.25^{\circ} \mathrm{C} ; I=0.1 \mathrm{M}, \mathrm{NaNO}_{3}\right)^{\mathrm{a}, \mathrm{b}}$

\begin{tabular}{|c|c|c|c|c|c|c|c|}
\hline $\mathrm{M}^{2+}$ & $\begin{array}{l}\log \\
\Delta_{\mathrm{M} / \mathrm{PME}-\mathrm{R}}\end{array}$ & $\begin{array}{l}\log \\
\Delta_{\mathrm{M} / 8,8 \mathrm{aPMEA}}\end{array}$ & $\begin{array}{l}\log \\
\Delta_{\mathrm{M} / 9,8 \mathrm{aPMEA}}\end{array}$ & $\begin{array}{l}\log \\
\Delta_{\mathrm{M} / \mathrm{PMEA}}\end{array}$ & $\begin{array}{l}\Delta \log \\
\Delta_{\mathrm{M} / 8,8 \mathrm{aPMEA} / \mathrm{PME}-\mathrm{R}}\end{array}$ & $\begin{array}{l}\Delta \log \\
\Delta_{\mathrm{M} / 9,8 \mathrm{aPMEA} / \mathrm{PME}-\mathrm{R}}\end{array}$ & $\begin{array}{l}\Delta \log \\
\Delta_{\mathrm{M} / \mathrm{PMEA} / \mathrm{PME}-\mathrm{R}}\end{array}$ \\
\hline $\mathrm{Mg}^{2+}$ & $0.16 \pm 0.04$ & $0.15 \pm 0.08$ & $0.14 \pm 0.05$ & $0.16 \pm 0.05$ & $-0.01 \pm 0.09$ & $-0.02 \pm 0.06$ & $0.00 \pm 0.06$ \\
\hline $\mathrm{Ca}^{2+}$ & $0.12 \pm 0.05$ & $0.06 \pm 0.06$ & $0.09 \pm 0.09$ & $0.11 \pm 0.07$ & $-0.06 \pm 0.08$ & $-0.03 \pm 0.10$ & $-0.01 \pm 0.09$ \\
\hline $\mathrm{Sr}^{2+}$ & $0.09 \pm 0.05$ & $0.08 \pm 0.05$ & $0.12 \pm 0.06$ & $0.07 \pm 0.05$ & $-0.01 \pm 0.07$ & $0.03 \pm 0.08$ & $-0.02 \pm 0.07$ \\
\hline $\mathrm{Ba}^{2+}$ & $0.11 \pm 0.05$ & $0.13 \pm 0.06$ & $0.16 \pm 0.06$ & $0.08 \pm 0.06$ & $0.02 \pm 0.08$ & $0.05 \pm 0.08$ & $-0.03 \pm 0.08$ \\
\hline $\mathrm{Mn}^{2+}$ & $0.19 \pm 0.06$ & $0.15 \pm 0.05$ & $0.18 \pm 0.06$ & $0.21 \pm 0.08$ & $-0.04 \pm 0.08$ & $-0.01 \pm 0.08$ & $0.02 \pm 0.10$ \\
\hline $\mathrm{Co}^{2+}$ & $0.20 \pm 0.06$ & $0.21 \pm 0.07$ & $0.25 \pm 0.07$ & $0.28 \pm 0.07$ & $0.01 \pm 0.09$ & $0.05 \pm 0.09$ & $0.08 \pm 0.09$ \\
\hline $\mathrm{Ni}^{2+}$ & $0.14 \pm 0.07$ & $0.18 \pm 0.06$ & $0.15 \pm 0.09$ & $0.30 \pm 0,07$ & $0.04 \pm 0.09$ & $0.01 \pm 0.11$ & $0.16 \pm 0.10$ \\
\hline $\mathrm{Cu}^{2+}$ & $0.48 \pm 0.07$ & $0.54 \pm 0.08$ & $0.81 \pm 0.07$ & $0.77 \pm 0.07$ & $0.06 \pm 0.11$ & $0.33 \pm 0.10$ & $0.29 \pm 0.10$ \\
\hline $\mathrm{Zn}^{2+}$ & $0.29 \pm 0.07$ & $0.31 \pm 0.11$ & $0.47 \pm 0.11$ & $0.30 \pm 0.10^{\mathrm{c}}$ & $0.02 \pm 0.13$ & $0.18 \pm 0.13$ & $0.01 \pm 0.12^{\mathrm{c}}$ \\
\hline $\mathrm{Cd}^{2+}$ & $0.30 \pm 0.05$ & $0.26 \pm 0.09$ & $0.28 \pm 0.08$ & $0.33 \pm 0.06$ & $-0.04 \pm 0.10$ & $-0.02 \pm 0.09$ & $0.03 \pm 0.08$ \\
\hline
\end{tabular}

${ }^{\mathrm{a}}$ For the error limits, see footnote (a) of Table 2

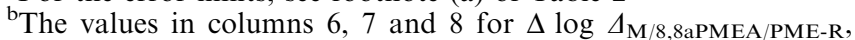
$\Delta \log \Delta_{\mathrm{M} / 9,8 \mathrm{aPMEA} / \mathrm{PME}-\mathrm{R}}$ and $\Delta \log \Delta_{\mathrm{M} / \mathrm{PMEA} / \mathrm{PME}-\mathrm{R}}$ (Eq. 11a,b) result from the comparison between the stability enhancements

right. Indeed, all the $\Delta \log \Delta_{\mathrm{M} / \mathrm{PMEA} / \mathrm{PME}-\mathrm{R}}$ values are again zero within their error limits, pointing again to the importance of equilibrium 1 , but there are also two exceptions, i.e. the $\mathrm{Ni}^{2+}$ and $\mathrm{Cu}^{2+}$ systems. In fact, the $\Delta \log \Delta_{\mathrm{Cu} / \mathrm{PMEA} / \mathrm{PME}-\mathrm{R}}$ value is identical with the one observed for $\Delta \log \Delta_{\mathrm{Cu} / 9,8 \mathrm{aPMEA} / \mathrm{PME}-\mathrm{R}}$; the meaning of this result will be discussed further below in the section " $\mathrm{Cu}(9,8 \mathrm{aPMEA})$ and related systems. A four isomer problem".

For the present we shall concentrate on those $18 \mathrm{M}(\mathrm{PA})$ systems for which $\Delta \log \Delta_{\mathrm{M} / \mathrm{PA} / \mathrm{PME}-\mathrm{R}}$ is zero within the error limits (see Table 4, columns 6 and 7) and for which the intramolecular equilibrium 1 operates.

The dimensionless intramolecular equilibrium constant, $K_{\mathrm{I} / \mathrm{O}}$, is defined by Eq. 13 ,

$K_{\mathrm{I} / \mathrm{O}}=\left[\mathrm{M}(\mathrm{PA})_{\mathrm{cl} / \mathrm{O}}\right] /\left[\mathrm{M}(\mathrm{PA})_{\mathrm{op}}\right]$

and values for $K_{\mathrm{I} / \mathrm{O}}$ can be calculated following known procedures $[47,51,62,65,72]$, i.e. via Eq. 14:

$K_{\mathrm{I} / \mathrm{O}}=10^{\log \Delta}-1$

Knowledge of $K_{\mathrm{I} / \mathrm{O}}$ then allows us, according to Eq. 15,

$\% \mathrm{M}(\mathrm{PA})_{\mathrm{cl} / \mathrm{O}}=100 \times K_{\mathrm{I} / \mathrm{O}} /\left(1+K_{\mathrm{I} / \mathrm{O}}\right)$

to obtain the percentage of the closed isomers, $\mathrm{M}(\mathrm{PA})_{\mathrm{cl} / \mathrm{O}}$, present in equilibrium 1, i.e. their formation degree. The corresponding results for the M(8,8aPMEA) and $\mathrm{M}(9,8 \mathrm{aPMEA})$ complexes are summarized in Table 5, where the values for the 9,8aPMEA ${ }^{2-}$ systems with $\mathrm{Cu}^{2+}$ and $\mathrm{Zn}^{2+}$ are given in parentheses for the reasons outlined above.

It is remarkable to observe that for a given metal ion the formation degree of the five-membered chelate involving the ether oxygen according to equilibrium 1 is, observed for the M(8,8aPME-R), M(9,8aPME-R) or M(PMEA) complexes and the ones for the M(PME-R) complexes, respectively ${ }^{\mathrm{c}}$ This value is an estimate since the stability constant for the $\mathrm{Zn}$ (PMEA) complex could not be measured due to precipitation [51]

within the error limits, identical for the complexes with both ligands, i.e. 8,8aPMEA ${ }^{2-}$ and 9,8aPMEA ${ }^{2-}$. This means that the 8 -azaadenine residue has no significant influence on the position of equilibrium 1 and that in all the complexes formed with $\mathrm{Mg}^{2+}, \mathrm{Ca}^{2+}, \mathrm{Sr}^{2+}, \mathrm{Ba}^{2+}$, $\mathrm{Mn}^{2+}, \mathrm{Co}^{2+}, \mathrm{Ni}^{2+}$ and $\mathrm{Cd}^{2+}$ these two ligands simply

Table 5 Extent of chelate formation according to equilibrium 1 as expressed by the dimensionless equilibrium constants $K_{\mathrm{I} / \mathrm{O}}$ (Eqs. 13 and 14) and the percentages of $\mathrm{M}(\mathrm{PA})_{\mathrm{cl} / \mathrm{O}}$ (Eq. 15), based on the $\log \Delta_{\mathrm{M} / \mathrm{PA}}$ values listed in column 5 of Table 3 for the M(8,8aPMEA) and M(9,8aPMEA) systems (aqueous solution; $\left.25^{\circ} \mathrm{C} ; I=0.1 \mathrm{M}, \mathrm{NaNO}_{3}\right)^{\mathrm{a}}$

\begin{tabular}{lllll}
\hline $\mathrm{PA}^{2-}$ & $\mathrm{M}^{2+}$ & $\log \Delta_{\mathrm{M} / \mathrm{PA}}$ & $K_{\mathrm{I} / \mathrm{O}}$ & $\% \mathrm{M}(\mathrm{PA})_{\mathrm{cl} / \mathrm{O}}$ \\
\hline $8,8 \mathrm{aPMEA}^{2-}$ & $\mathrm{Mg}^{2+}$ & $0.15 \pm 0.08$ & $0.41 \pm 0.26$ & $29 \pm 13$ \\
& $\mathrm{Ca}^{2+}$ & $0.06 \pm 0.06$ & $0.15 \pm 0.16$ & $13 \pm 12$ \\
& $\mathrm{Sr}^{2+}$ & $0.08 \pm 0.05$ & $0.20 \pm 0.14$ & $17 \pm 10$ \\
& $\mathrm{Ba}^{2+}$ & $0.13 \pm 0.06$ & $0.35 \pm 0.19$ & $26 \pm 10$ \\
& $\mathrm{Mn}^{2+}$ & $0.15 \pm 0.05$ & $0.41 \pm 0.16$ & $29 \pm 8$ \\
& $\mathrm{Co}^{2+}$ & $0.21 \pm 0.07$ & $0.62 \pm 0.26$ & $38 \pm 10$ \\
& $\mathrm{Ni}^{2+}$ & $0.18 \pm 0.06$ & $0.51 \pm 0.21$ & $34 \pm 9$ \\
& $\mathrm{Cu}^{2+}$ & $0.54 \pm 0.08$ & $2.46 \pm 0.64$ & $71 \pm 5$ \\
& $\mathrm{Zn}^{2+}$ & $0.31 \pm 0.11$ & $1.04 \pm 0.52$ & $51 \pm 12$ \\
& $\mathrm{Cd}^{2+}$ & $0.26 \pm 0.09$ & $0.82 \pm 0.38$ & $45 \pm 11$ \\
$9,8 \mathrm{aPMEA}$ & $2-$ & & \\
& $\mathrm{Mg}^{2+}$ & $0.14 \pm 0.05$ & $0.38 \pm 0.16$ & $28 \pm 8$ \\
& $\mathrm{Ca}^{2+}$ & $0.09 \pm 0.09$ & $0.23 \pm 0.26$ & $19 \pm 17$ \\
& $\mathrm{Sr}^{2+}$ & $0.12 \pm 0.06$ & $0.32 \pm 0.18$ & $24 \pm 10$ \\
& $\mathrm{Ba}^{2+}$ & $0.16 \pm 0.06$ & $0.45 \pm 0.20$ & $31 \pm 10$ \\
$\mathrm{Mn}^{2+}$ & $0.18 \pm 0.06$ & $0.51 \pm 0.21$ & $34 \pm 9$ \\
$\mathrm{Co}^{2+}$ & $0.25 \pm 0.07$ & $0.78 \pm 0.29$ & $44 \pm 9$ \\
& $\mathrm{Ni}^{2+}$ & $0.15 \pm 0.09$ & $0.41 \pm 0.29$ & $29 \pm 15$ \\
& $\mathrm{Cu}^{2+}$ & $0.81 \pm 0.07$ & $(5.46 \pm 1.04)^{\mathrm{b}}$ & $(85 \pm 2)^{\mathrm{b}}$ \\
& $\mathrm{Zn}^{2+}$ & $0.47 \pm 0.11$ & $(1.95 \pm 0.75)^{\mathrm{b}}$ & $(66 \pm 9)^{\mathrm{b}}$ \\
$\mathrm{Cd}^{2+}$ & $0.28 \pm 0.08$ & $0.91 \pm 0.35$ & $48 \pm 10$ \\
& & &
\end{tabular}

${ }^{\mathrm{a}}$ For the error limits, see footnote (a) of Table 2

${ }^{\mathrm{b}}$ The parentheses indicate that the stability increase cannot solely be attributed to equilibrium 1 since in these systems a contribution from a nucleobase-metal ion interaction also exists [41]. See also the section " $\mathrm{Cu}(9,8 \mathrm{aPMEA})$ and related systems. A four isomer problem" 
behave as a PME- $\mathrm{R}^{2-}$ ligand, $\mathrm{R}-\mathrm{CH}_{2} \mathrm{CH}_{2}-\mathrm{O}-\mathrm{CH}_{2}$ $\mathrm{PO}_{3}^{2-}$, where $\mathrm{R}$ does neither participate in metal ion binding nor affect it in a negative sense, e.g. by steric inhibition.

\section{$\mathrm{Cu}(9,8 \mathrm{aPMEA})$ and related systems. A four isomer problem}

The values for $\Delta \log \Delta_{\mathrm{Cu} / \mathrm{PA} / \mathrm{PME}-\mathrm{R}}$ due to the $\mathrm{Cu}(9,8 \mathrm{aPMEA})$ and $\mathrm{Cu}(\mathrm{PMEA})$ complexes are identical (Table 4, columns 7 and 8) and in both instances the increased stability is clearly beyond that attributable to equilibrium 1 with the ether oxygen interaction and it is further clear that the additional interaction must be with the adenine residue. The additional stability increase due to $\Delta \log \Delta_{\mathrm{Zn} / 9,8 \mathrm{aPMEA} / \mathrm{PME}-\mathrm{R}}$ for the $\mathrm{Zn}(9,8 \mathrm{aPMEA})$ system is clearly also beyond the error limits (Table 4, column 7). The apparent lack of such an increased stability for the $\mathrm{Zn}$ (PMEA) system (Table 4, column 8) is no surprise, as the data for this system are based on an estimation $[22,23,51]$, though one should note that, owing to the relatively large error limits of the values for the $\mathrm{Zn}(\mathrm{PMEA})$ and $\mathrm{Zn}(9,8 \mathrm{aPMEA})$ systems, the $\Delta \log$ $\Delta_{\mathrm{Zn} / \mathrm{PA} / \mathrm{PME}-\mathrm{R}}$ values overlap, hence, the properties of the two systems are probably similar.

For the Ni(9,8aPMEA) and Ni(PMEA) systems (Table 4, columns 7 and 8) the differing situation is more complicated to rationalize, since there were no experimental difficulties. The $\Delta \log \Delta_{\mathrm{Ni} / \mathrm{PMEA} / \mathrm{PME}-\mathrm{R}}$ value for the latter system and, hence, a $\mathrm{Ni}^{2+}$-adenine residue interaction, appears as being certain. The difference between these two systems, $0.15 \pm 0.15$ $[=(0.16 \pm 0.10)-(0.01 \pm 0.11)]$, seems also to be real, especially when one takes into account that the given error is based on $3 \sigma$; the value for $1 \sigma$, i.e. $0.15 \pm 0.05$, still corresponds to a confidence interval of about $70 \%$. Hence, it appears that the $\mathrm{Ni}^{2+}-(\mathrm{N} 7)$ interaction is hampered in the $\mathrm{Ni}(9,8 \mathrm{aPMEA})$ system, whereas in the Ni(PMEA) complex exactly this isomer occurs to a considerable formation degree [41]. It should be noted that in the $\mathrm{Cu}^{2+}$ and $\mathrm{Zn}^{2+}$ systems the macrochelated isomer involving $\mathrm{N} 7$ is a minority species (see below) and therefore no differences in the complexing

$$
\begin{aligned}
& \mathrm{M}^{2+}+\mathrm{PA}^{2-} \stackrel{K_{\mathrm{M}(\mathrm{PA})_{\mathrm{op}}}^{\mathrm{M}}}{\rightleftharpoons} \mathrm{M}(\mathrm{PA})_{\mathrm{op}} \underset{K_{\mathrm{l} / \mathrm{O}}}{\stackrel{K_{\mathrm{l} / \mathrm{N} 7}}{\rightleftharpoons} \mathrm{M}(\mathrm{PA})_{\mathrm{c} / \mathrm{O}}} \\
& \left\{K_{\mathrm{I} / \mathrm{O} / \mathrm{N} 3}\right. \\
& \mathrm{M}(\mathrm{PA})_{\mathrm{Cl} / \mathrm{O} / \mathrm{N} 3}
\end{aligned}
$$

properties between PMEA $^{2-}$ and 9,8aPMEA ${ }^{2-}$ show up for these two metal ions. With $\mathrm{Ni}^{2+}$ this is different [41], as mentioned, but it may be explained with the reduced basicity of N7 in 9,8aPMEA ${ }^{2-}$ which is due to the effect of the neighbouring $\mathrm{N} 8$ atom.

To complete the picture, the results regarding the previously established $[41,46]$ equilibrium scheme 16 need to be summarized shortly. The two isomeric species $\mathrm{M}(\mathrm{PA})_{\mathrm{op}}$ and $\mathrm{M}(\mathrm{PA})_{\mathrm{cl} / \mathrm{O}}$ have been discussed and defined above; they correspond to equilibrium 1 . The species $\mathrm{M}(\mathrm{PA})_{\mathrm{cl} / \mathrm{N} 7}$ represents a third isomer and corresponds to the macrochelate seen in equilibrium 2 which is formed via N7. Finally, the fourth isomer in which not only a five-membered chelate involving the phosphate group and the ether oxygen exists, but in which in addition also a seven-membered chelate involving the N3 site is formed, is abbreviated as $\mathrm{M}(\mathrm{PA})_{\mathrm{cl} / \mathrm{O} / \mathrm{N} 3}$.

The most thoroughly studied system of this kind is $\mathrm{Cu}(\mathrm{PMEA})$ [46]: the formation degrees for any $\mathrm{Cu}(\mathrm{PMEA})$ complex concentrations are $17 \pm 3 \%$, $34 \pm 10 \%, 41 \pm 12 \%$ and $7.7 \pm 5.3 \%$ (errors $3 \sigma$ ) for $\mathrm{Cu}(\mathrm{PMEA})_{\mathrm{op}}, \mathrm{Cu}(\mathrm{PMEA})_{\mathrm{cl} / \mathrm{O}}, \mathrm{Cu}(\mathrm{PMEA})_{\mathrm{cl} / \mathrm{O} / \mathrm{N} 3}$ and $\mathrm{Cu}(\mathrm{PMEA})_{\mathrm{cl} / \mathrm{N} 7}$, respectively, showing that the macrochelated isomer involving N7 is a minority species; the important isomers involve the ether oxygen either in the form of $\mathrm{Cu}(\mathrm{PMEA})_{\mathrm{cl} / \mathrm{O}}$ or together with $\mathrm{N} 3$ as

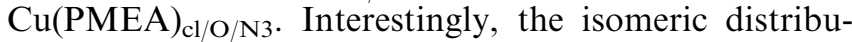
tion for the $\mathrm{Cu}(9,8 \mathrm{aPMEA})$ system is within the error limits $(3 \sigma)$ identical with that for the mentioned $\mathrm{Cu}\left(\right.$ PMEA) system; the values for $\mathrm{Cu}(9,8 \text { PMEA })_{\text {op }}$, $\mathrm{Cu}(9,8 \mathrm{aPMEA})_{\mathrm{cl} / \mathrm{O}}, \quad \mathrm{Cu}(9,8 \mathrm{aPMEA})_{\mathrm{cl} / \mathrm{O} / \mathrm{N} 3}$ and $\mathrm{Cu}(9,8 \mathrm{aPMEA})_{\mathrm{cl} / \mathrm{N} 7}$ are $15 \pm 3 \%, 30 \pm 10 \%, 48 \pm 11 \%$ and $6.8 \pm 4.7 \%$, respectively [41]. This demonstrates how closely related PMEA $^{2-}$ and 9,8aPMEA ${ }^{2-}$ are in their metal ion-binding properties, whereas $8,8 \mathrm{aPMEA}^{2-}$ is clearly quite different in this respect.

Of further interest is the $\mathrm{Zn}(9,8 \mathrm{aPMEA})$ system [41] (see Table 5, the second entry from below), of which $34 \pm 8 \%$ exist as the $\mathrm{Zn}(9,8 \mathrm{aPMEA})_{\text {op }}$ isomer, whereas $32 \pm 13 \%, 24 \pm 26 \%$ and $10 \pm 21 \%$ are present as $\mathrm{Zn}(9,8 \mathrm{aPMEA})_{\mathrm{cl} / \mathrm{O}}, \quad \mathrm{Zn}(9,8 \mathrm{aPMEA})_{\mathrm{cl} / \mathrm{O} / \mathrm{N} 3}$ and $\mathrm{Zn}(9,8 \mathrm{aPMEA})_{\mathrm{cl} / \mathrm{N} 7}$, respectively. Two points need to be made here: (1) the total amount of chelated species encompasses $66 \%(=32+24+10)$, as already given in parentheses in Table 5; (2) the large error limits $(3 \sigma$; confidence limits $99.7 \%$ ) need to be put into perspective, i.e. if the error limits are given with one standard deviation $(1 \sigma)$, which corresponds to a confidence limit of about $70 \%$, the results for $\mathrm{Zn}(9,8 \mathrm{aPMEA})_{\mathrm{cl} / \mathrm{O}}$, $\mathrm{Zn}(9,8 \mathrm{aPMEA})_{\mathrm{cl} / \mathrm{O} / \mathrm{N} 3}$ and $\mathrm{Zn}(9,8 \mathrm{aPMEA})_{\mathrm{cl} / \mathrm{N} 7}$ are $32 \pm$ $4 \%, 24 \pm 9 \%$ and $10 \pm 7 \%$, respectively. Again, the chelated isomers involving the ether oxygen are the dominating ones among the "closed" species and the macrochelated isomer involving N7 is also in this case a minority species.

\section{Conclusions}

The present results show that the metal ion-binding properties of 9,8aPMEA ${ }^{2-}$ very closely resemble those of PMEA $^{2-}$ itself, including the extent of the $\mathrm{M}^{2+}$-ether 
oxygen interaction. It is thus not surprising that 9,8aPMEA also shows antiviral activity [26, 33, 74], although it appears to be somewhat less active but also less toxic [74]. This contrasts with 8,8aPMEA which shows no useful biological activity $[26,33]$ and this despite the fact that also in its complexes an ether oxygen-metal ion interaction occurs and that it occurs with biologically meaningful metal ions like $\mathrm{Mg}^{2+}, \mathrm{Ca}^{2+}$ or $\mathrm{Mn}^{2+}$ to the same extent as with 9,8aPMEA ${ }^{2-}$ or PMEA ${ }^{2-}$ itself. However, since in the 8-aza isomer the orientation of the adenine residue is different than in PMEA, whereas in the 9-aza isomer it is identical, this observation regarding the biological activity is no surprise.

Indeed, owing to this different orientation of the nucleobase moiety, also its binding properties towards metal ions with an $\mathrm{N}$ affinity, like $\mathrm{Cu}^{2+}$, are different. In 9-substituted PAs a nucleobase interaction is possible and with ions like $\mathrm{Cu}^{2+}$ it actually occurs. In contrast, 8,8aPMEA ${ }^{2-}$ behaves in its complexing properties like a PME- ${ }^{2-}$ ligand, which offers no binding site in its residue R. Since in the active site cavity the anchoring process of a substrate is important $[22,23]$, and because this process involves the nucleobase residue and dictates thus the orientation of the substrate, one may conclude that at least one of the reasons for the inactivity of $8,8 \mathrm{aPMEA}$ is a presumably different orientation in the active site of the polymerase.

In fact, if one considers the structure-function relationship for nucleotide analogues, one may conclude the following: if one assumes that 8,8aPMEA and 9,8aPMEA are transported to the cell and also diphos phorylated like PMEA [75, 76, 77, 78], then it becomes understandable why 9,8aPMEA shows antiviral activity and 8 ,8aPMEA does not [26,33]. The 9-aza isomer is structure-wise so similar to PMEA itself (see Fig. 1) that a facilitated $\mathrm{M}\left(\mathrm{P}_{\alpha}\right)$ binding (via the ether oxygen) is possible with 9,8aPMEApp ${ }^{4-}$ and thus also the formation of the $\mathrm{M}\left(\mathrm{P}_{\alpha}\right)-\mathrm{M}\left(\mathrm{P}_{\beta}, \mathrm{P}_{\gamma}\right)$ binding mode, which is crucial for the transfer of a nucleotidyl unit in the polymerase reaction $[22,23]$. In contrast, 8,8 aPMEA is anchored with a different orientation (due to hydrogen bonding and stacking [42]) in the active site cavity of the polymerase, which prevents formation of the indicated reactive binding mode. To conclude, for biological activity of an acyclic nucleoside phosphonate derivative the ether oxygen is compulsory, but it must also be correctly orientated in space to become effective.

Acknowledgements The competent technical assistance of Mrs Rita Baumbusch and Mrs Astrid Sigel in the preparation of this manuscript as well as stimulating discussions with members of the COST D20 programme are gratefully acknowledged. This study was supported by the Swiss National Science Foundation (H.S.) and the Programme of Targeted Projects (S4055109) of the Academy of Sciences of the Czech Republic (A.H.) as well as within the COST D20 programme by the Swiss Federal Office for Education and Science (H.S.) and the Ministry of Education of the Czech Republic (D20.002; A.H.). This study also received support from the University of Basel and it is further part of a research project (no 4055905) of the Institute of Organic Chemistry and Biochemistry (IOCB) in Prague.

\section{References}

1. Tamm I, Folkers K, Shunk CH (1956) J Bacteriol 72:59-64

2. Martin JC (ed) (1989) Nucleotide analogs as antiviral agents. (ACS symposium series 401) American Chemical Society, Washington, DC, pp 1-190

3. Sigel RKO, Song B, Sigel H (1997) J Am Chem Soc 119:744-755

4. Holý A (2003) Curr Pharm Des 9:2567-2592

5. Holý A, Günter J, Dvořáková H, Masojídková M, Andrei G, Snoeck R, Balzarini J, De Clercq E (1999) J Med Chem 42:2064-2086

6. Holý A, Votruba I, Masojídková M, Andrei G, Snoeck R, Naesens L, De Clercq E, Balzarini J, (2002) J Med Chem 45:1918-1929

7. De Clercq E (1998) Collect Czech Chem Commun 63:449-479

8. De Clercq E (1998) Collect Czech Chem Commun 63:480-506

9. Keith KA, Hitchcock MJM, Lee WA, Holý A, Kern ER (2003) Antimicrob Agents Chemother 47:2193-2198

10. De Clercq E, Holý A, Rosenberg I, Sakuma T, Balzarini J, Maudgal PC (1986) Nature 323:464-467

11. Tribolet R, Sigel H (1987) Eur J Biochem 163:353-363

12. Aoki K (1996) Met Ions Biol Syst 32:91-134

13. Blindauer CA, Holý A, Dvořáková H, Sigel H (1997) J Chem Soc Perkin Trans 2 2353-2363

14. Pelletier H, Sawaya MR, Kumar A, Wilson SH, Kraut J (1994) Science 264:1891-1903

15. Pelletier H, Sawaya MR, Wolfle W, Wilson SH, Kraut J (1996) Biochemistry 35:12762-12777

16. Brautigam CA, Steitz TA (1998) Curr Opinion Struct Biol 8:54-63

17. Sigel H (1992) Inorg Chim Acta 198-200:1-11

18. Sigel H (1990) Coord Chem Rev 100:453-539

19. Sigel H, Song B, Blindauer CA, Kapinos LE, Gregáň F, Prónayová N (1999) Chem Commun 743-744

20. Holý A, De Clercq E, Votruba I (1989) ACS Symp Ser 401:51-71

21. Holý A, Votruba I, Merta A, Černý J, Veselý J, Vlach J, Šedivá K, Rosenberg I, Otmar M, Hřebabecký H, Trávníček M, Vonka V, Snoeck R, De Clercq E (1990) Antiviral Res 13:295-311

22. Sigel H (1999) Pure Appl Chem 71:1727-1740

23. Sigel H (2004) Chem Soc Rev 33:191-200

24. Villemin D, Thibault-Starzyk F (1993) Synth Commun 23:1053-1059

25. Holý A, Rosenberg I, Dvořáková H (1990) Collect Czech Chem Commun 55:809-818

26. Holý A, Dvořáková H, Jindřich J, Masojídková M, Buděšínský M, Balzarini J, Andrei G, De Clercq E (1996) J Med Chem 39:4073-4088

27. Roblin RO Jr, Lampen JO, English JP, Cole QP, Vanghan JR Jr (1945) J Am Chem Soc 67:290-294

28. Kidder GW, Dewey VC, Parks RE Jr, Woodside GL (1949) Science 109:511-514

29. Singh P, Hodgson DJ (1977) J Am Chem Soc 99:4807-4815

30. Sheldrick WS, Bell P (1986) Inorg Chim Acta 123:181-187

31. Sheldrick WS, Bell P (1989) Inorg Chim Acta 160:265-271

32. Franchetti P, Abu Sheikha G, Cappellacci L, Grifantini M, De Montis A, Piras G, Loi AG, La Colla P (1995) J Med Chem 38:4007-4013

33. Dvořáková H, Holý A, Masojídková M, Votruba I, Balzarini J, Snoeck R, De Clercq E (1993) Collect Czech Chem Commun $58: 253-255$

34. Sigel H (1995) Coord Chem Rev 144:287-319

35. Blindauer CA, Emwas AH, Holý A, Dvořáková H, Sletten E, Sigel H (1997) Chem Eur J 3:1526-1536

36. Blindauer CA, Holý A, Dvořáková H, Sigel H (1998) J Biol Inorg Chem 3:423-433

37. Sigel H, Massoud SS, Tribolet R (1988) J Am Chem Soc 110:6857-6865

38. Sigel H (1993) Chem Soc Rev 22:255-267

39. Sigel H (2004) Pure Appl Chem 76:375-388

40. Bianchi EM, Sajadi SAA, Song B, Sigel H (2003) Chem Eur J 9:881-892 
41. Gómez-Coca RB, Holý A, Vilaplana RA, González-Vílchez F, Sigel H (2004) Bioinorg Chem Applicat 2:(in press)

42. Gómez-Coca RB, Kapinos LE, Holý A, Vilaplana RA, González-Vílchez F, Sigel H (2000) Metal Based Drugs 7:313-324

43. Sigel H, Zuberbühler AD, Yamauchi O (1991) Anal Chim Acta 255:63-72

44. Irving HM, Miles MG, Pettit LD (1967) Anal Chim Acta $38: 475-488$

45. Blindauer CA, Sjåstad TI, Holý A, Sletten E, Sigel H (1999) J Chem Soc Dalton Trans 3661-3671

46. Gómez-Coca RB, Kapinos LE, Holý A, Vilaplana RA, González-Vílchez F, Sigel H (2000) J Chem Soc Dalton Trans 20772084

47. Martin RB, Sigel H (1988) Comments Inorg Chem 6:285-314

48. Kapinos LE, Song B, Sigel H (1999) Chem Eur J 5:1794-1802

49. Kapinos LE, Song B, Sigel H (1998) Inorg Chim Acta 280:50-56

50. Kapinos LE, Sigel H (2002) Inorg Chim Acta 337:131-142

51. Sigel H, Chen D, Corfù NA, Gregáň F, Holý A, Strašák M (1992) Helv Chim Acta 75:2634-2656

52. Yamauchi O, Odani A, Masuda H, Sigel H (1996) Met Ions Biol Syst 32:207-270

53. Scheller KH, Hofstetter F, Mitchell PR, Prijs B, Sigel H (1981) J Am Chem Soc 103:247-260

54. Kampf G, Kapinos LE, Griesser R, Lippert B, Sigel H (2002) J Chem Soc Perkin Trans 2 1320-1327

55. Sigel H (2004) Pure Appl Chem 76:(in press)

56. Sheldrick WS, Heeb G (1991) Inorg Chim Acta 190:241-248

57. Albert A (1969) J Chem Soc (C) 152-160

58. Blindauer CA, Holý A, Sigel H (1999) Collect Czech Chem Commun 64:613-632

59. Kapinos LE, Kampf G, Griesser R, Lippert B, Sigel H (1999) Chimia 53:348
60. Sigel H, Da Costa CP, Song B, Carloni P, Gregáň F (1999) J Am Chem Soc 121:6248-6257

61. Da Costa CP, Sigel H (1999) J Biol Inorg Chem 4:508-514

62. Sigel H, Massoud SS, Corfù NA (1994) J Am Chem Soc 116:2958-2971

63. Sigel H, McCormick DB (1970) Acc Chem Res 3:201-208

64. Saha A, Saha N, Ji L, Zhao J, Gregáň F, Sajadi SAA, Song B, Sigel H (1996) J Biol Inorg Chem 1:231-238

65. Sigel H, Song B (1996) Met Ions Biol Syst 32:135-205

66. Sajadi SAA, Song B, Gregáň F, Sigel H (1999) Inorg Chem 38:439-448

67. Irving HM, Williams RJP (1953) J Chem Soc: 3192-3210

68. Sigel H, Lippert B (1998) Pure Appl Chem 70:845-854

69. Griesser R, Kampf G, Kapinos LE, Komeda S, Lippert B, Reedijk J, Sigel H (2003) Inorg Chem 42:32-41

70. Sigel H, Corfù NA, Ji L-n, Martin RB (1992) Comments Inorg Chem 13:35-59

71. Martin RB (1996) Met Ions Biol Syst 32:61-89

72. Sigel H, Kapinos LE (2000) Coord Chem Rev 200-202:563-594

73. Massoud SS, Sigel H (1988) Inorg Chem 27:1447-1453

74. Franchetti P, Abu Sheikha G, Cappellacci L, Messini L, Grifantini M, Loi AG, De Montis A, Spiga MG, La Colla P (1994) Nucleosides Nucleotides 13:1707-1719

75. Merta A, Votruba I, Rosenberg I, Otmar M, Hřebabecký H, Bernaerts R, Holý A (1990) Antiviral Res 13:209-218

76. Robbins BL, Greenhaw J, Connelly MC, Fridland A (1995) Antimicrob Agents Chemother 39:2304-2308

77. Kramata P, Votruba I, Otová B, Holý A (1996) Mol Pharmacol 49:1005-1011

78. Birkuš G, Votruba I, Holý A, Otová B (1999) Biochem Pharmacol 58:487-492 